\title{
A QUESTÃO DA PAISAGEM NO BRASIL ATRAVÉS DE ROBERTO BURLE MARX
}

\author{
THE LANDSCAPE QUESTION IN BRAZIL THROUGH ROBERTO BURLE MARX
}

\author{
Alexandra Maria Aguiar Leister*
}

\section{RESUMO}

No Brasil, as paisagens de Burle Marx enriquecem o pensamento sobre a paisagem, emprestado, com frequência, de autores internacionais. Este artigo, debruçando-se no referencial teórico dos campos da filosofia e da geografia, conduziu uma reflexão em torno da paisagem com base nas obras do mestre brasileiro Roberto Burle Marx. Sua caminhada profissional revela uma contribuição singular no aprofundamento da questão da paisagem. Como uma díade, sua concepção teórica da natureza transformava-se em paisagens vivenciáveis. Nesse processo etéreo, construiu lugares dignos de despertar olhares sensíveis. Este artigo reflete os conceitos teóricos de Burle Marx sobre a paisagem, sua maneira de transformá-los em projetos paisagísticos e suas considerações em relação ao futuro da paisagem brasileira.

Palavras-chave: Paisagem. Natureza. Burle Marx. Paisagismo.

\section{ABSTRACT}

Burle Marx believed that the landscape's aesthetic dimension was an essential concept for human life. In Brasil, Burle Marx's landscapes enrich our thoughts on landscape architecture, often borrowed from international authors. In this context, this article, based on the theoretical framework of philosophy and geography, leads to a reflection on landscape based on the works of the Brazilian master of landscapes, Roberto Burle Marx. His professional career is a unique contribution to deepening the issue of landscape. As a dyad, his theoretical concepts of nature were transformed into livable landscapes. In this ethereal process, the master built places worthy of awakening the senses. This article reflects on his theoretical concepts of landscape, the way he transformed them into landscape architecture projects and his thoughts about the future of the Brazilian landscape.

Keywords: Landscape. Nature. Burle Marx. Landscape architecture.

\section{PAISAGEM, NATUREZA E ARTE}

"Nunca mais encontraremos a paz do Éden, mas poderemos tentar nos aproximar dela, criando ambientes repousantes e que enlevem." (Burle Marx, 1962, p. 67).

A escalada do Monte Ventoux' por Francesco Petrarca, em 1335, preludia o olhar moderno sobre a paisagem. Sob o olhar do homem, a natureza, pela primei-

Monte Ventoux, ou Monte Ventor (em português), é uma montanha que faz parte dos Alpes Ocidentais da França.

\footnotetext{
Mestra em Arquitetura Paisagística pela Universidade do Texas em Arlington e em Design Sustentável do Ambiente Construído pela Universidade Britânica em Dubai, Universidade Cardiff. Doutoranda na Faculdade de Arquitetura e Urbanismo da Universidade de São Paulo (FAUUSP) - Área de Concentração Paisagem e Ambiente. Bolsista da Coordenação de Aperfeiçoamento de Pessoal de Nível Superior (Capes).

CV: http://lattes.cnpq.br/5185156364161316
} 
ra vez, é contemplada. A luta entre interior e exterior - durante a experiência despertada apenas "[...] pelo desejo de ver um lugar reputado por sua altura [...]"2 - surpreendeu o poeta. Ao deparar-se com a paisagem e com o "[...] ar estranhamente leve e pelo espetáculo grandioso [... $]^{\prime \prime 3}$, a paisagem tomou-o de estupefação. (PETRARCA, 1336, p. 68). Ao ler as palavras de Santo Agostinho, porém, o filósofo encontrava-se "[...] irritado com a admiração que ainda sentia pelas coisas terrestres, quando deveria há tempo ter aprendido, dos próprios filósofos pagãos, que não há nada de admirável fora da alma, que nada é grande diante da sua grandeza"4. (PETRARCA, 1336, p. 70-71).

Para Philippe Nys (1997, p. 35), a experiência da subida ao Ventoux, apesar de conflitante, foi "[...] fundadora de uma hermenêutica da paisagem como experiência

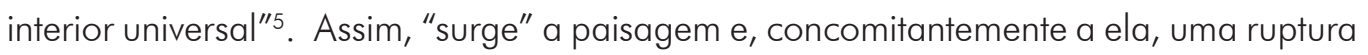
da relação do homem com a natureza. Posteriormente, apesar de no final do século XV serem documentados usos do termo "paisagem" - frequentemente associados à pintura de paisagens no Renascimento -, apenas seis séculos após a subida ao Ventoux a questão desabrocha na filosofia, na geografia, na pintura e na poesia.

Georg Simmel ${ }^{6}$ (1913), sociólogo e pioneiro na teorização da questão da paisagem como categoria do pensamento humano, defendeu em seu texto inaugural sobre a paisagem - La tragédie de la culture et autres essais - que esta é um processo espiritual, que o gosto pela paisagem exige separação do sentimento unitário de natureza. Por sua vez, a natureza é a totalidade; não possui fragmentos. É a cadeia infinita do universo, "[...] unidade fluida do movimento de transformação". (SIMMEL, 1913, p. 25). Por outro lado, a paisagem é a delimitação da natureza em um raio visual fugaz ou mesmo prolongado. $O$ olhar humano, ao remanejar e dividir a natureza em unidades particulares, cria paisagens. E o maior suporte dessas unidades é descrito por Simmel como "Stimmung" da paisagem" (1913) ou "atmosfera da paisagem":

2,3 Extraído de Familiarum Rerum Libri IV, I. Traduzida do latim para o francês por Denis Montebello. Tradução do francês para o português por Vladimir Bartalini, com a finalidade exclusiva de subsidiar as disciplinas AUP 5834, A paisagem no desenho do cotidiano urbano, e AUP 5882, Paisagem e arte - intervenções contemporâneas, do curso de pós-graduação da Faculdade de Arquitetura e Urbanismo da Universidade de São Paulo. São Paulo: FAUUSP, 2013.

4,5 Tradução do francês para o português por Vladimir Bartalini, com a finalidade exclusiva de subsidiar as disciplinas AUP 5834, A paisagem no desenho do cotidiano urbano, e AUP 5882, Paisagem e arte - intervenções contemporâneas, do curso de pós-graduação da Faculdade de Arquitetura e Urbanismo da Universidade de São Paulo. São Paulo: FAUUSP, 2013.

6 SIMMEL, Georg. La tragédie de la culture: et autres essais. Tradução de Sabine Cornille e Philippe Ivernel. Paris: Editions Rivages, 1988. Tradução do francês para o português por Vladimir Bartalini, com a finalidade exclusiva de subsidiar as disciplinas AUP 5834, A paisagem no desenho do cotidiano urbano, e AUP 5882, Paisagem e arte - intervenções contemporâneas, do curso de pós-graduação da Faculdade de Arquitetura e Urbanismo da Universidade de São Paulo. São Paulo: FAUUSP, 2013.

7,8 De acordo com Bartalini (2013, p. 15), a palavra Stimmung pode ser aproximadamente traduzida como "atmosfera" ou "estado da alma". 
A paisagem [...] nasce no momento em que fenômenos naturais justapostos sobre o solo terrestre são reagrupados em um modo particular de unidade, diferente daquela compreendida no campo de visão do pensador com seu pensamento causal, do adorador da natureza com seu sentimento religioso, do trabalhador ou do estrategista com sua orientação finalista. (SIMMEL, 1913, p. 25).

Paisagem é percepção. A Stimmung ${ }^{8}$ ou "atmosfera", "estado da alma", fundamentada na paisagem, exige demarcação e não deve ser confundida com natureza, pois esta é o todo, não tem fragmentos e vai além da compreensão sistemática de classificação dos seus elementos. Simmel (1913, p. 25) defende que o olhar sobre a paisagem está além da observação circunstanciada da natureza. É um "[...] estado psíquico e reside no reflexo afetivo do espectador e não nas coisas exteriores desprovidas de consciência[...]". É necessário que tal conteúdo cative nossos espíritos, pois a Stimmung de uma paisagem é objetiva e ligada à paisagem, porém, como ressaltou Assunto (2013), cada indivíduo possui uma visão específica, conectada ao afloramento de sua unidade formal.

Simmel (1913) indaga se a Stimmung não seria uma formação espiritual, por não ser palpável e só viver na alma, mas ressalta que não se trata de um conceito abstrato, pelo fato de cada paisagem possuir sua própria Stimmung, ou seja, essa atmosfera se resume ao sentimento desencadeado pela paisagem no espectador, e esse sentimento, em sua forma mais legítima, está vinculado tão somente à paisagem particularmente vivenciada.

Em seu texto "Paisagem: função da estética na sociedade moderna"9, Joachim Ritter, historiador da filosofia alemã, diz: "[...] a paisagem é a natureza esteticamente presente se mostrando a um ser que a contempla provando sentimentos". (RITTER, 1978, p. 55). A natureza presente no cotidiano das cidades ou a natureza bucólica, contexto da vida no campo, por si só não são paisagens, isto é, essas cenas "[...] só se tornam paisagem para o homem que se volta a elas para fruir livremente do seu espetáculo e para estar ele próprio no seio da natureza, sem visar finalidades práticas". (RITTER, 1978, p. 55).

Ritter (1978) ressalta que o significado da escalada de Petrarca estava relacionado com os motivos da escalada. Naquele momento existia um contexto intelectual que permitia "[...] o interesse pela natureza enquanto paisagem [...]" e sua contemplação, ou Theoria tou Kosmou. Para o autor, "[...] contemplação na natureza significa sempre que o espírito se volta para o 'Todo', para o 'Divino'". (RITTER, 1978, p. 50). Assim sendo:

[...] a natureza em sua totalidade não encontra mais sua expressão em um conceito científico que não fala mais do cév e da terra, é a impressão sensível que passa a fornecer a imagem e a linguagem estéticas e poéticas que permitem representá-la em seu pertencimento à nossa existência e fazer sua verdade. (RITTER, 1978, p. 60).

RITTER, Joachim. Paysage: fonction de l'esthétique dans la société moderne. Tradução de Gerard Raulet. Besançon: Les Éditions de Lĺmprimeur, 1997. Tradução do original alemão para o francês de Gerard Raulet. Tradução do francês para o português de Vladimir Bartalini, com a finalidade exclusiva de subsidiar as disciplinas AUP 5834, A paisagem no desenho do cotidiano urbano, e AUP 5882, Paisagem e arte - intervenções contemporâneas. São Paulo: FAUUSP, 2013. 
O historiador ainda reflete sobre o poema de Schiller, "A Promenade" (1795), no qual a interpretação da paisagem ocorre em função da liberdade e da reificação da paisagem, ou seja, viver livre é dominar a natureza. "A fruição estética e o interesse pela natureza têm, então, por condições prévias a liberdade e a dominação da sociedade sobre a natureza." (RITTER, 1978, p. 64). Diante da expansão urbana, a natureza, menos evidente nas cidades, vira objeto e deixa de exercer sua função primária de subsistência. $\bigcirc$ homem passa a dominá-la e contemplá-la.

Para Augustin Berque (1994), geógrafo orientalista, o sentido da paisagem reside na interação complexa entre o objeto e o sujeito. Para sua construção teórica, o autor emprega os termos "mediança", o sentido estabelecido entre o subjetivo (sociedade) e o objetivo (ambiente físico); "trajeção", um movimento de constante troca entre o mundo subjetivo e o mundo objetivo compondo a realidade dos meios. "Marcada ao mesmo tempo por mediança e historicidade a paisagem é trajetiva."10 (BERQUE, 1994, p. 41). Por fim, utiliza o termo "ecúmena", que descreve a relação do homem com a extensão terrestre habitável: "A paisagem é uma entidade relativa e dinâmica, onde natureza e sociedade, olhar e ambiente estão em constante interação." (BERQUE, 1994, p. 26). Portanto, segundo o autor, a paisagem não é evidente, não existe de forma igual para todos e nem existe em todas as épocas, pois é um fenômeno particular e implicado na vida social.

Com esse mesmo sentido, porém se debruçando sobre a paisagem sustentada por alicerces do mundo natural, Adriana Serrão (2004) assim apresenta a questão:

Paisagem refere, em sentido amplo, uma porção de natureza, uma parte da realidade natural, uma unidade diferenciada contendo os seres naturais no seu elemento próprio. Resguarda, portanto, a solidez de um conjunto, integrando nele seus elementos e também todo o enquadramento vital. Um conjunto não idealizado, mas real, presente e, enquanto tal, visível e sensível, que se oferece à percepção. (SERRÃO, 2004, p. 91).

Serrão (2004, p. 92) apresenta as teorias do filósofo Rosário Assunto para demarcar uma categoria da paisagem natural, baseada na filosofia, que seja distinta das interpretações de "vista ou lugar de vista, panorama, enquadramento, quadro natural, moldura, fundo das coisas e das formas"; a paisagem como parte da natureza é a experiência do homem nela, ou seja, a paisagem "é sempre a experiência de nós vivendo nela". (ASSUNTO, 1994 apud SERRÃO, 2004, p. 92). Assunto (2013) trata a paisagem através da filosofia estética e metafísica, explica Serrão (2014), tirando-a da "[...] esfera das representações e imagens para a colocar na ordem do ser; [...] antes de ser uma qualquer representação do mundo, a paisagem é um lugar do mundo onde a natureza se torna objecto de uma experiência integral".

10 BERQUE, Augustin. Cinq propositions pour une théorie du paysage. Tradução do original por Vladimir Bar-talini com a finalidade exclusiva de subsidiar a disciplina AUP 5810, Paisagismo do curso de Pós-Graduação da Faculdade de Arquitetura e Urbanismo da Universidade de São Paulo, 2013. 
Paisagem é a "forma" na qual se exprime a unidade sintética a priori (no sentido kantiano: não a "unificação" de dados recebidos separadamente, mas a "unidade" necessária que condiciona o seu apresentar-se na consciência) da "matéria (território)" e do "conteúdo ou função (ambiente)". [...] $\bigcirc$ ambiente concreto, o ambiente que vivemos e do qual vivemos vivendo nele, é sempre o ambiente como forma de um território: paisagem. (ASSUNTO, 1994 apud SERRÃO, 2004, p. 93).

Segundo Serrão (2014), o processo amplo de modernização iniciado com a industrialização da sociedade foi responsável pelo rompimento entre cultura e natureza "[...] ameaçando a própria sobrevivência do fundamento natural". A atual situação demanda princípios orientadores no conhecimento e no agir, e a ideia de paisagem pode restaurar a unidade do Mundo, pois a "[...] categoria de Paisagem oferece múltiplas potencialidades de síntese e permitirá, colmatando brechas, estabelecer transições num mundo ameaçado de desagregação". (SERRÃO, 2014, p. 4).

De tendências opostas, a filosofia da paisagem reúne diversas perspectivas, "[...] a ontologia, na determinação da essência e das qualidades intrínsecas da paisagem [...]", isto é: a união entre espacialidade e temporalidade; a estética, que vai além do belo e do sublime como meios de apreciar e valorizar; a "[...] ética, ao tomar posição sobre o sentido, a possibilidade e os limites do agir humano". (SERRÃO, 2014). Dessa forma, a filósofa adota a paisagem como categoria mediadora em problemas iminentes, como "[...] a destruição da cidade tradicional e do equilíbrio entre urbano e o rural; a crise da natureza e a dúvida sobre a naturalidade do natural; a crise ecológica e o advento da consciência ambientalista". (SERRÃO, 2014, p. 5).

Considerando-se a polissemia da paisagem, alguns conceitos usados hoje no Brasil ancoram-se largamente em publicações com traduções de autores estrangeiros, assim como explicou Bartalini (2012, p. 6): "[...] não há títulos brasileiros que se proponham a tratá-la numa perspectiva própria, substantiva, em que a paisagem, enquanto assunto a ser contemplado teoricamente, considerado a partir de uma posição clara de uma intenção deliberada (ou seja, de uma thesis) não seja diluída ou subentendida em outros temas". No entanto, apesar de não se dispor, significativamente, de publicações que conjeturem a paisagem como objeto de contemplação, dispõe-se das obras de Roberto Burle Marx, sejam pinturas, livros, jardins, anotações ou palestras. Nesse sentido, poderia ser pleiteado que o legado de Burle Marx é basilar para discussões sobre a paisagem no Brasil, posto que suas obras ainda hoje refletem questões sociais, paisagísticas e ambientais que estimulam íntimas reflexões sobre a natureza, a cidade e a arte enquanto formações anímicas.

Nessa perspectiva, cabe ressaltar sua contribuição para, por exemplo, a discussão da paisagem como categoria mediadora em problemas de desequilíbrio ambiental ou mesmo para reflexões sobre como nossa sociedade relaciona-se com a natureza. A paisagem, praticamente desconsiderada durante a Idade Média, que aflorou com o nascimento da pintura no Renascimento, é ainda hoje um tema complexo para as ciências, e, muitas vezes, ignoto ao leigo. 
Se na Antiguidade ou Idade Média a religiosidade era a principal causa da falta do "sentimento de natureza", gerando conflitos da alma e medo do desconhecido, poderia hoje a exiguidade desse sentimento estar enraizada no desenvolvimento urbano vertiginoso e na tecnologização? Em tempo algum se esteve tão perto da natureza e dos seus processos. Cenas extraordinárias, em alta definição, de lugares que nunca se sonharia em visitar estão ao alcance de nossas mãos. Os benefícios tecnológicos são incalculáveis, porém, como disse o filósofo, "[...] o fato de observarmos a natureza e suas mutações, ou distinguir cada detalhe não seria o suficiente para vermos uma paisagem". (SIMMEL, 1913, p. 20). Seria preciso que tal conteúdo cativasse nossos espíritos.

O progresso seduz e dificulta nosso contato direto com o mundo natural. A paisagem, quando não é percebida, não consegue "cativar". A natureza, que em regiões mais urbanizadas é quimérica, muitas vezes não é vivenciada e, talvez, desperte menos a curiosidade. Regressa-se, assim, aos sentimentos arcaicos de medo do desconhecido. A natureza, hoje, é estranha para muitos. A industrialização, que moldou a sociedade moderna, alterou drasticamente muitas paisagens em que o "civilizado" reprime os resquícios de natureza existentes nas cidades. A destruição da paisagem deveria ser motivo de indignação social, porém falta, às vezes, o olhar sensível para questões da natureza, e por esse motivo a conscientização da população sobre a "relevância pública da paisagem" é essencial. (QUEIROGA, 2012, p. 27).

Se a pintura conseguiu aflorar o sentimento de paisagem no homem moderno, 0 que então poderia desabrochar esse sentimento no homem contemporâneo? $\bigcirc$ homem chegou à contemporaneidade tecnicamente munido, socialmente conectado através das mídias e confiante na dominação do universo, porém é preciso estar atento para não se desmembrar da natureza, parte essencial da sua existência. Com a agilidade da devastação de muitas de nossas paisagens tropicais, será difícil ter montes para escalar ou paisagens para contemplar. Será a tecnologia o "diretor de consciência agostiniano" do homem, que, assim como Petrarca, não o deixa usufruir dessa experiência? Como, então, despertar o olhar sensível, que possa resgatar o sentimento de paisagem no Brasil? Alain Roger (1999, p. 1) explica:

[...] a percepção, histórica e cultural, de todas as nossas paisagens - campo, montanha, mar, deserto, etc. - não requer qualquer intervenção mística (como se elas descessem do céu ou misteriosa como se elas saíssem do chão), ela se opera segundo o que denomino, retomando uma palavra de Montaigne, uma artialização."

11 ROGER, A. O nascimento da paisagem no ocidente. In: BARTALINI, Vladimir. COLÓQUIO INTERNACIONAL DE HISTÓRIA DA ARTE, 10, São Paulo, 1999. Tradução do francês para o português por Vladimir Bartalini, com a finalidade exclusiva de subscidiar as disciplinas AUP 5834, A paisagem no desenho do cotidiano urbano, e AUP 5882, Paisagem e arte - intervenções contemporâneas do curso de pós-graduação da Faculdade de Arquitetura e Urbanismo da Universidade de São Paulo. São Paulo: FAUUSP, $2^{\circ}$ sem. 2013. 
Segundo o autor, pode-se artializar um país para transformá-lo em paisagem in situ, por exemplo, através dos jardins ou da Land Art. ${ }^{12}$ Dessa forma, inscreve-se diretamente o "[...] código artístico da materialidade do lugar, no terreno, a base natural". A outra maneira de artializar um país seria in visu, ou seja, indireta e "[...] sobre o olhar coletivo, fornecendo-lhe modelos de visão, esquemas de percepção e de deleite". (ROGER, 1999 , p. 1). Nesse caso, os jardins, que através dos paisagistas ganham forma e são parte de um processo cultural e social, tornam-se elementos importantes, pois, segundo Roger (1999), podem permitir a visualização da paisagem.

Nessa lógica, a complexidade e a dimensão das obras de Burle Marx são experiências capazes de fornecer ao observador inúmeras oportunidades de perceber a paisagem através das formas, cores e texturas. Como disse McHarg, Marx "[...] sintetizou sua busca por arte com o seu conhecimento de plantas. Ele entendeu a beleza da flora nativa, e elevou o uso de plantas brasileiras para uma forma de arte com seus projetos".13 (McHARG, 1996, p. 126). Através da sua formação de "[...] arquiteto- paisagista, ambientalista, botânico, jardineiro, pintor, desenhista, gravador, tapeceiro, escultor, professor de pintura, designer de joias, cantor lírico [...]" (DOURADO, 2009, p. 9) ele transformava a natureza em obras inestimáveis, capazes de despertar o olhar sensível. Marx transcendeu a teoria e transformou conceitos paisagísticos, de arte, de sociedade e cultura em matéria, ou seja, "artializou" o Brasil. Sua conceituação filosófica da paisagem construída baseava-se, como ele mesmo definia:

[...] na direção histórica de todas as épocas, reconhecendo, em cada período, a expressão do pensamento estético que se manifesta nas demais artes. Neste sentido a minha obra reflete a modernidade, a data em que se processa, porém jamais perde de vista as razões da própria tradição, que são válidas e solicitadas. Se me indagassem qual a primeira atitude filosófica assumida para o meu jardim, logo responderia ser exatamente a mesma que traduz o comportamento do homem neolítico: aquela de alterar a natureza topográfica, para ajustar a existência humana, individual e coletiva, utilitária e prazerosa [...] (MARX, 2004a, p. 24).

A arte e o cuidado em ensejar a "percepção" através de suas obras revelam-se constantes em sua trajetória. Em conferência proferida em 1966, Burle Marx expôs suas considerações sobre a arte e a paisagem brasileiras:

12 A Land Art, "[...] arte que é feita diretamente na paisagem, esculpindo a própria terra em terraplenagem ou fazendo estruturas na paisagem usando materiais naturais, como pedras ou galhos [...]" (TATE LAND ART, 2015), visava à contramão da superficialidade e comercialização da arte americana dos anos 1960. Muitos exemplos bem-sucedidos de projetos de Land Art estão entre renomados artistas norte-americanos e europeus, como Robert Smithson, Christo, Walter de Maria e Richard Long. No Brasil esse movimento teve pouca repercurssão. Apesar do início promissor, com obras de Cildo Meirelles na década de 1960, como "Mutações geográficas: fronteira Rio-São Paulo", a Land Art não encontrou a mesma força que nos países estrangeiros. No entanto, esse enfraquecimento pode ser consequência do foco da crítica da época em artistas especializados em esculturas, instalações ou "galerias", não atribuindo ao paisagismo a condição de arte.

13 "[...] he synthetized his pursuit of art with his knowledge of plants. He understood the beauty of native flora, and elevated the use of Brazilian plants to an artform with his designs". (McHARG, 1996, p. 126). O texto em português é uma tradução livre feita pela pesquisadora. 
[...] o artista plástico deve tomar o seu vocabulário da observação da fauna humana, seus hábitos, costumes e contradições, situando-os e relacionando-os à natureza e à paisagem, à qual esta imprime seu caráter e é por ela modelado para que, através de sua visão pessoal, com sua própria maneira de expressão, consiga transmitir a sua mensagem de emoção poética. (MARX, 2004b, p. 72).

Nessa perspectiva, cabe ressaltar a relevância do campo do paisagismo para o enriquecimento de discussões sobre o tema da paisagem, que atualmente encontram-se enraizadas na geografia e, principalmente, na filosofia. Burle Marx ensinou que 0 paisagista, além de oferecer novos olhares sobre a paisagem, pode também despertar no homem citadino, através de obras paisagísticas, o olhar sensível para ela:

A missão social do paisagista tem esse lado pedagógico de fazer comunicar às multidões o sentimento de apreço e compreensão dos valores da natureza pelo contato com o jardim e com o parque. No Brasil, onde há, em parte, esse desamor pelo que é plantado, a lição da experiência me ensinou que é preciso insistir muitas vezes para, por meio do choque entre as posições, trazer o entendimento da importância da nossa ação e contribuição, a fim de provocar uma mudança na mentalidade [...] (MARX, 2004c, p. 94).

A Stimmung das paisagens criadas por Burle Marx estimula a relação do homem com a natureza e desperta emoções, iá que a paisagem, como explica Ferriolo (1997), emana da theoria e é fruto do homem que sai para a natureza. Através dos parques, jardins, bosques e praças, somos resgatados, por um momento, da ebulição da vida nas metrópoles, pois a paisagem que instiga a contemplação da natureza contribui para um olhar para o "Todo", para o "Divino". Além disso, as obras paisagísticas de Roberto Burle Marx demonstram possibilidades numerosas de como criar lugares que provocam, fascinam e, consequentemente, despertam o sentimento de paisagem.

\section{TRANSFORMANDO A PAISAGEM}

A questão da paisagem alcança, nas obras de Burle Marx, uma teoria com conceitos e objetivos desanuviados. Sua reflexão, centrada na importância de intervir de maneira consciente nas paisagens, é sintetizada pelo diálogo com o lugar e uso da natureza como arte, valorizando também a flora autóctone. Por meio do exercício do paisagismo, Burle Marx transformou a natureza em espaços de contemplação na cidade. Assim como Simmel (1913, p. 21), expôs: "[...] a natureza, que no seu ser e no seu sentido profundos ignora toda individualidade, é remanejada pelo olhar humano [...]". Burle Marx, em sua conceituação da paisagem, ensina:

O que é constante nela é a visão. [...] tudo aquilo que abarcamos com o olhar; [...] não é estática, pois todos os seus elementos constituintes são passíveis de transformação própria como também se alteram mutuamente; um território é formado 
por um número infinito de paisagens, parcialmente justapostas; e embora o termo paisagem não informe nada acerca de suas características, é evidente que qualquer vista tem, para o observador, uma série de elementos que a definem e que a diferenciam de outras infinitas paisagens. (MARX, 2004d, p. 127).

Suas obras demonstram como a paisagem é "pontual e irrepetível". (SERRÃO, 2013). Sua conceituação filosófica da paisagem construída fundamentava-se na direção histórica de todas as épocas, identificando, em cada período, a expressão do pensamento estético manifestada nas demais artes. Suas obras refletiam a modernidade e a data em que aconteciam, nunca, entretanto, perdendo de vista as "[...] razões da própria tradição". (MARX, 2004a).

No projeto da residência Nininha Magalhães Lins, no Rio de Janeiro (RJ), pode-se observar a criação de paisagens que seduzem os olhos humanos através da sutil manipulação da natureza que se dilui na paisagem intocada do horizonte (figuras 1, 2 e 3). Um traço permanente de suas obras sempre foi o diálogo com o lugar, às vezes concordando e conectando-se com a paisagem, outras vezes cuidadosamente negando o entorno, buscando soluções estético-funcionais para tornar o lugar agradável. (MARX, 2004).

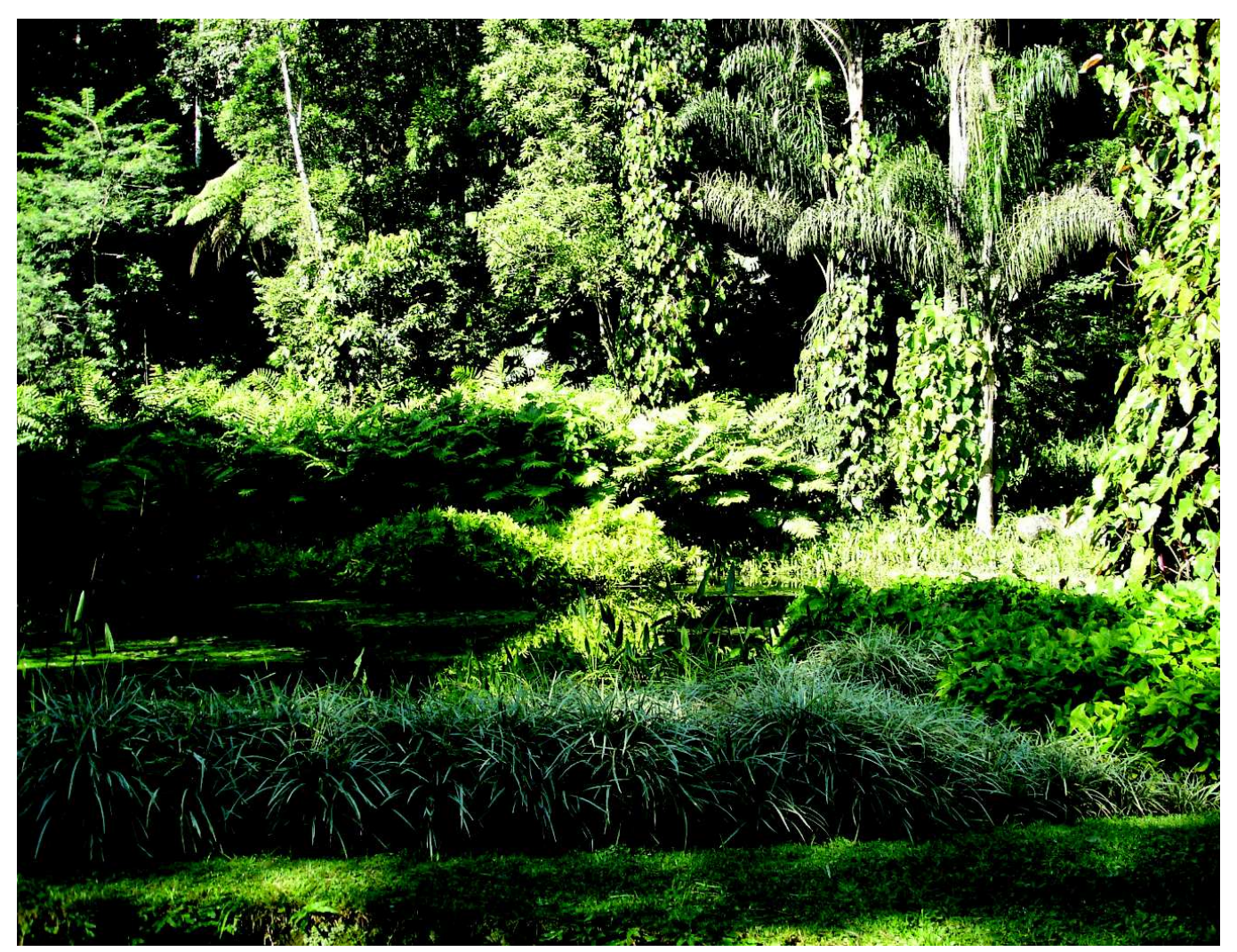

Figura 1 Residência Nininha Magalhães Lins, Rio de Janeiro, RJ, jul. 2005. Foto: Acervo Quapá. 


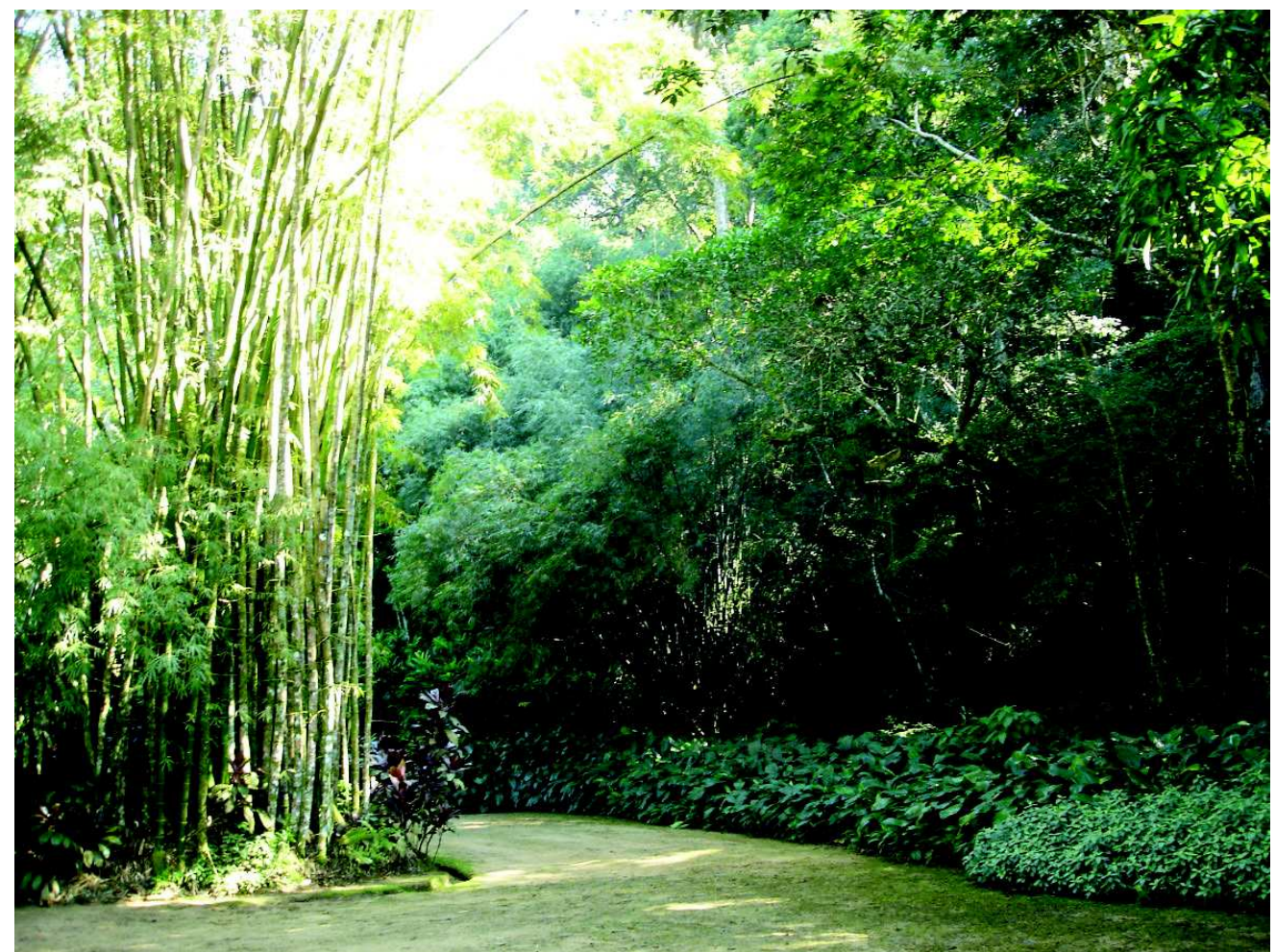

Figura 2 Residência Nininha Magalhães Lins, Rio de Janeiro, RJ, 2005. Foto: Acervo Quapá

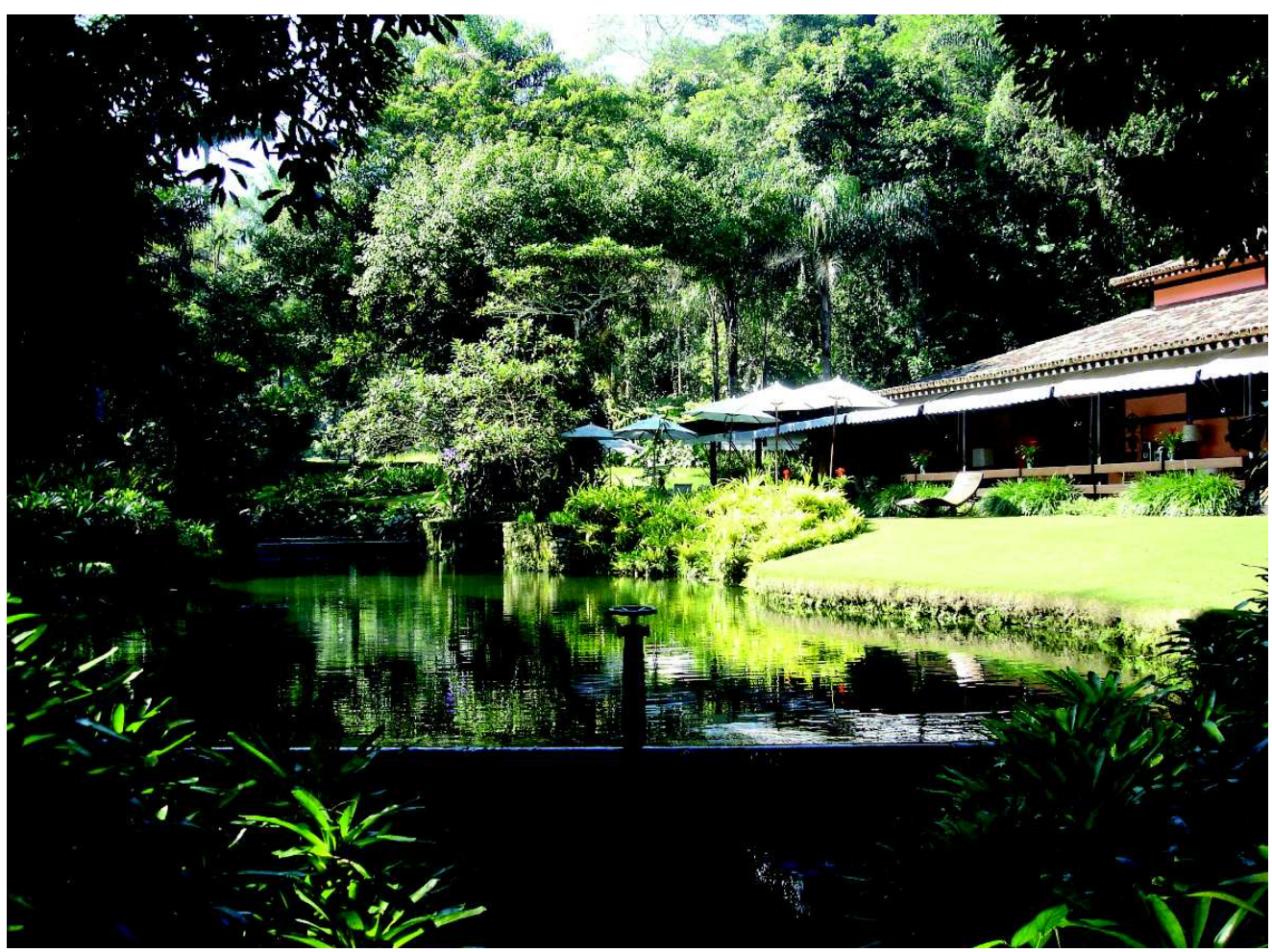

Figura 3 Residência Nininha Magalhães Lins, Rio de Janeiro, RJ, jul. 2005. Foto: Acervo Quapá. 
Em 1962, o paisagista declarou que "[...] a arte do planejamento de um jardim é muito - talvez a mais - complexa, exigindo compreensão de outras artes, uma disposição de aprender com a natureza". (MARX, 2004, p. 54). A partir da cuidadosa harmonização dos elementos naturais, plausíveis de serem moldados, como árvores, arbustos, flores, forrações e pedras, Burle Marx pincelava a paisagem. Os processos naturais imprevisíveis também poderiam proporcionar momentos únicos, capazes de despertar sentimentos, a Stimmung, nos jardins. "Nuvens e chuvas podem mudar a forma de um jardim. Toda a sua proporção pode ser alterada quando os reflexos desaparecem ou quando uma tempestade súbita deposita poças d'água em lugares imprevistos." (MARX, 2004e, p. 56).

Assim, Marx (2004) mostrou como a justaposição dos atributos plásticos do cubismo e do abstracionismo aos elementos naturais o atraíam para novas experiências de criação de paisagens para serem contempladas. Ele utilizava a topografia natural como uma superfície para a composição, dando aos elementos da natureza encontrados no local a função de materiais de organização plástica, criando projetos únicos dentro de uma unidade, miscigenando a arte da pintura com a da paisagem construída. Muitas de suas obras ancoraram suavemente edifícios monumentais à topografia, harmoniosamente integrando-os à paisagem, como no projeto do edifício do BNDES (figura 4).

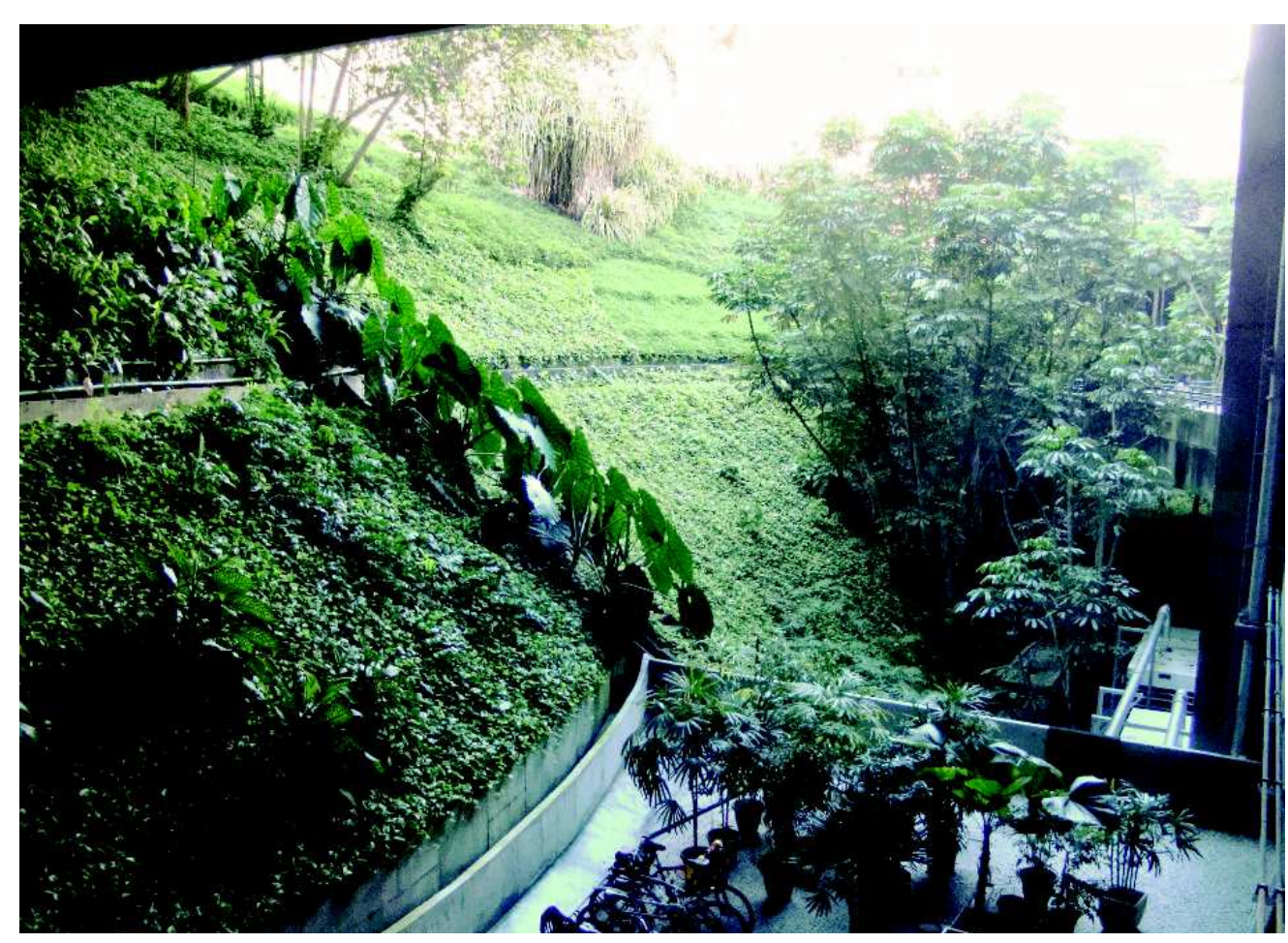

Figura 4 Edifício do Banco Nacional de Desenvolvimento Econômico e Social (BNDES), Rio de Janeiro, RJ, 2010. Foto: Acervo Quapá.

Da mesma forma, nos jardins do edifício Macunaíma em São Paulo (figuras 5, 6 e 7), construído em 1980, a natureza, que delicadamente permeia a edificação, desperta 


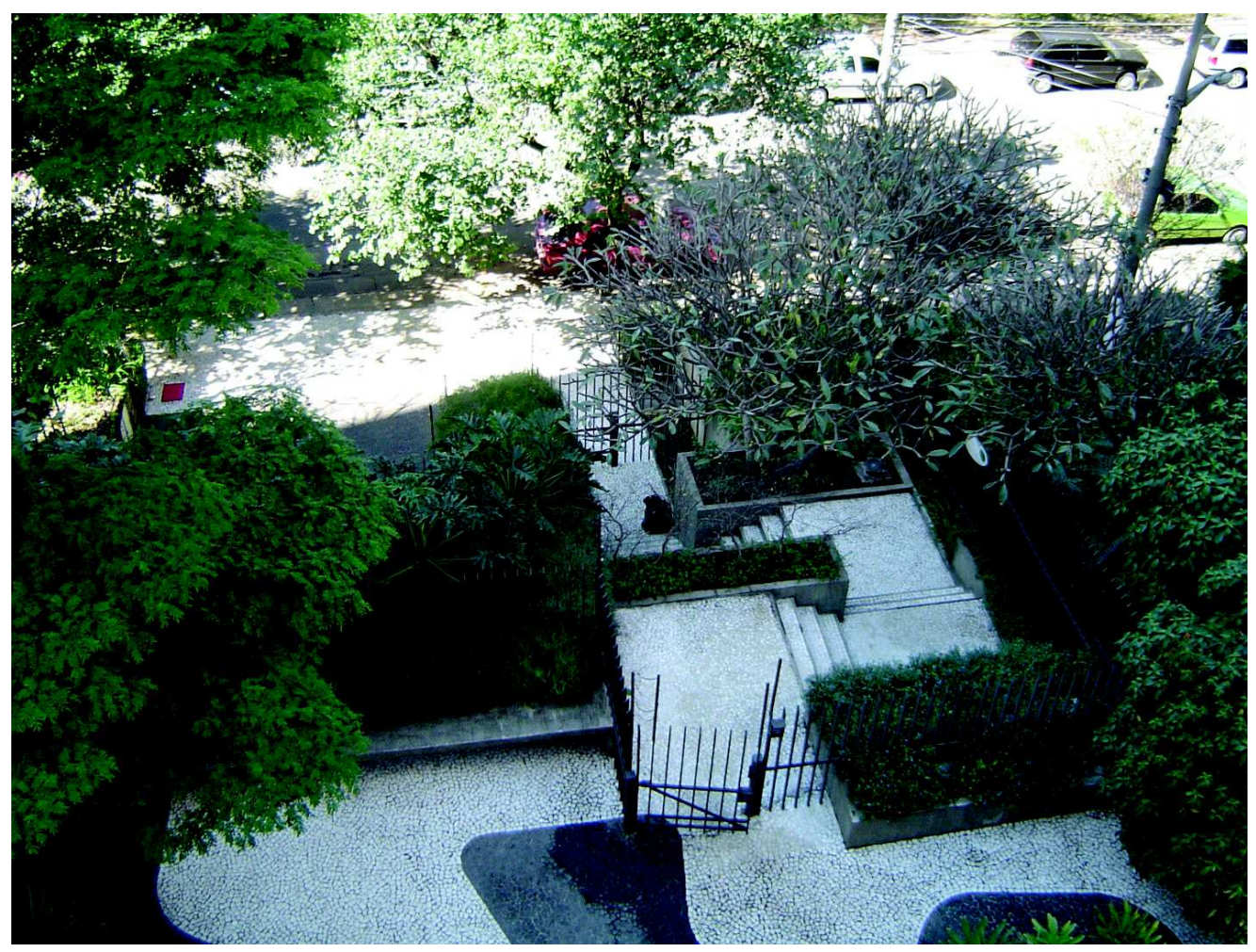

Figura 5 Edifício Macunaíma, São Paulo, SP, 2005. Foto: Acervo Quapá.

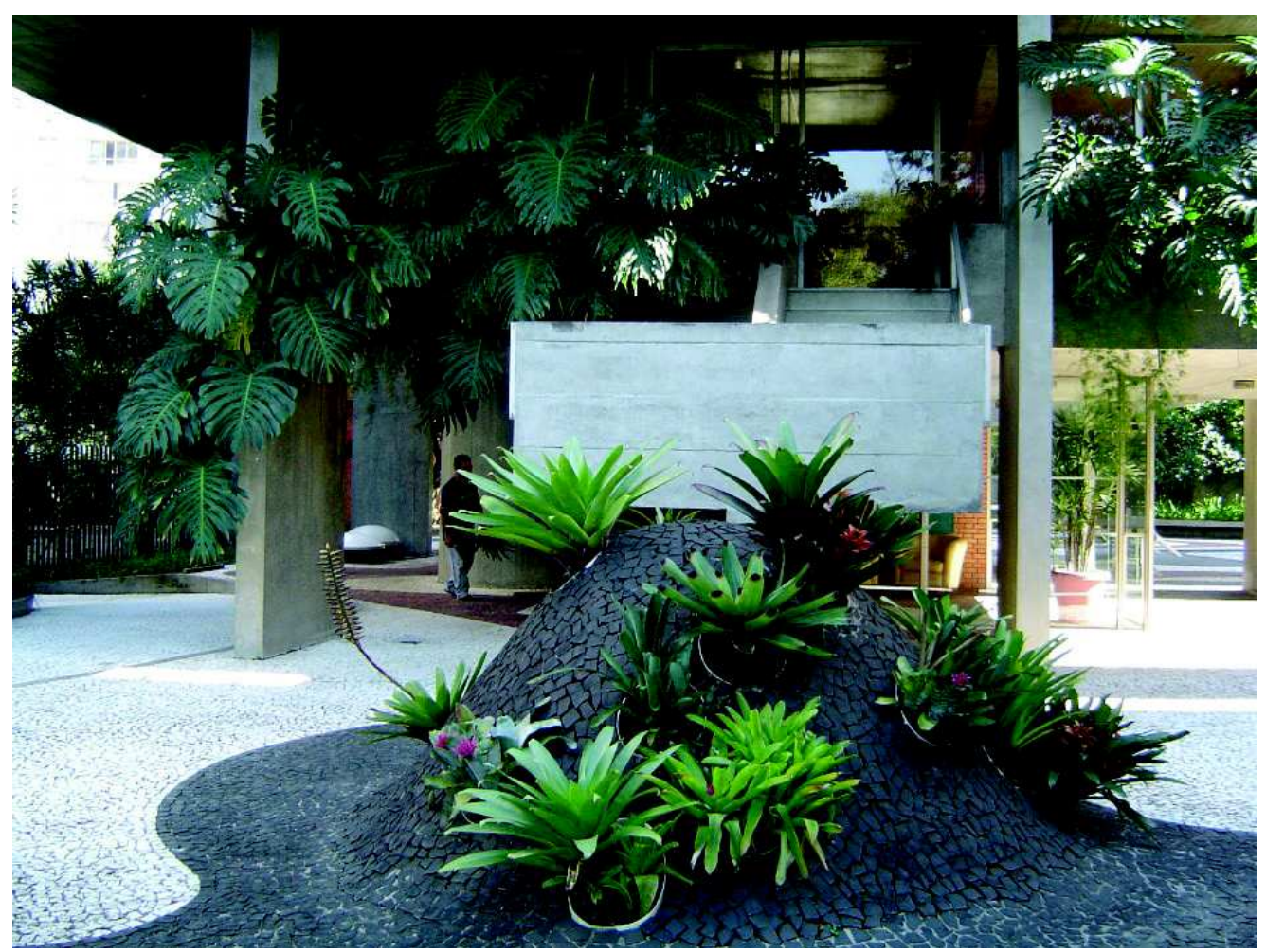

Figura 6 Edifício Macunaíma, São Paulo, SP, 2005.

Foto: Acervo Quapá. 
- olhar sensível através de elementos paisagísticos e artísticos, como os "cupins", como designados por Marx os montes de terras cobertos por pedra portuguesa - de onde saem bromélias, suavizando as fortes linhas arquitetônicas e ancorando o edifício à paisagem.

Suas composições valorizavam elementos da flora nativa, retratando uma nova visão estética no uso da vegetação. No projeto do jardim público Praça de Casa Forte (1934), em Recife (figuras 8 a 12), Marx enriqueceu sua obra com o uso de espécies nativas brasileiras da região amazônica e da mata atlântica, como a vitória-régia amazônica e a sibipiruna. Ao mesmo tempo, o uso de espécies estrangeiras em um jardim de forte traçado geométrico de inspiração europeia conseguia dialogar com o lugar e transformá-lo em agradáveis espaços públicos para conduzir a experiências de contemplação da paisagem. $\bigcirc$ projeto de uma praça inserida na malha urbana não se resumia apenas a um ato cultural de construção, mas de novos valores e percepções sobre elementos da paisagem nordestina em consonância com a paisagem urbana.

Com linhas mais orgânicas, porém marcantes, a praça Ministro Salgado Filho (figuras 13 a 17), ou Praça do Aeroporto, como conhecida em Recife, um projeto de 1957, contrapõe-se suavemente ao entorno onde está inserida. Através de traços que se assemelham às suas pinturas, Burle Marx concebe um jardim que se destaca na malha urbana e sincronicamente produz experiências espaciais através dos maciços de vegetação, ora negando o entorno, ora expondo-o, utilizando-se de formas abstratas para criar ambientes que despertam a apreciação dos jardins e do entorno.

No caso do projeto do Aterro do Flamengo, no Rio de Janeiro (figuras 18, 19 e 20), seus conceitos transformam-se em manifestação de um lugar que dialoga sincronicamente com a cidade e com a natureza existente, criando um poderoso espaço livre urbano que propicia diversas oportunidades de vivenciar a paisagem tropical. Sua perspicácia na compreensão do espaço, entre a rigidez da cidade de um lado e a delicadeza da baía do outro, faz do projeto do Aterro um lugar que se relaciona magistralmente com o entorno.

As paisagens circundantes do Rio de Janeiro, seja a cidade ou os morros, foram harmoniosamente integradas aos espaços, reforçando seu conhecimento e uso, muitas vezes simultâneo, das artes plásticas e paisagísticas em suas criações do espaço. De acordo com Tabacow, muitas vezes é instintivo fazer paralelos entre a pintura, jardins e esculturas nas obras do paisagista, pois ele "[...] tinha sempre presente as peculiaridades de cada uma dessas formas de manifestação e jamais desconsiderava as características e sutilezas inerentes a ela". (MARX, 2004a, p. 25).

Sutilizas tão enraizadas em seu olhar, que Marx refletia constantemente sobre a cultura jardinística brasileira, onde roseiras, gerânios, cravos e crisântemos, entre outras espécies de vegetação de origem europeia, dominavam os jardins da época. Imigrantes europeus traziam em sua bagagem a paisagem deixada para trás e transformavam nossas paisagens para servir às suas memórias. Interessante observar, ainda hoje, que essa cultura estrangeira de jardins permeia nossa pátria. Temos, de alguma forma, a tendência de valorizar o estrangeiro, desde os carros até as plantas. Burle Marx (2004f) 
dizia que, ao saber que as exuberantes espécies que utilizava em suas obras eram brasileiras, havia um desinteresse profundo das pessoas. Nesse sentido, ele afirmava que o papel do paisagista é singular, pois pode interferir na destruição incontrolável da natureza:

Se, em nossas especificações de vegetação, nos projetos, procurarmos utilizar a flora autóctone, e o que é muito importante, se lutarmos para essa especificação ser concretizada, estaremos salvando muitas plantas do perigo do desparecimento. (MARX, 2004f, p. 168).

Burle Marx sempre buscava referências na paisagem do lugar e no reconhecimento da flora autóctone para intervenções conscientes e sensíveis, pois a compreensão da vegetação local pode contribuir para um paisagista intervir de forma mais equilibrada no ambiente. A transformação da paisagem exige o olhar sensível do paisagista, que deve ser capaz de compreender as diferentes fases da natureza, seus processos e suas singularidades, para antever a transformação da paisagem com o tempo. "[...] A planta é um ser vivo, a exigir suas próprias condições. Mas, a um pequeno preço, ela nos compensa com sua própria dinâmica, com a da floração, frutificação, queda das folhas e até com a morte". (MARX, 2004f, p. 168). E até na morte Marx encontrava beleza e criava paisagens (figura 21).

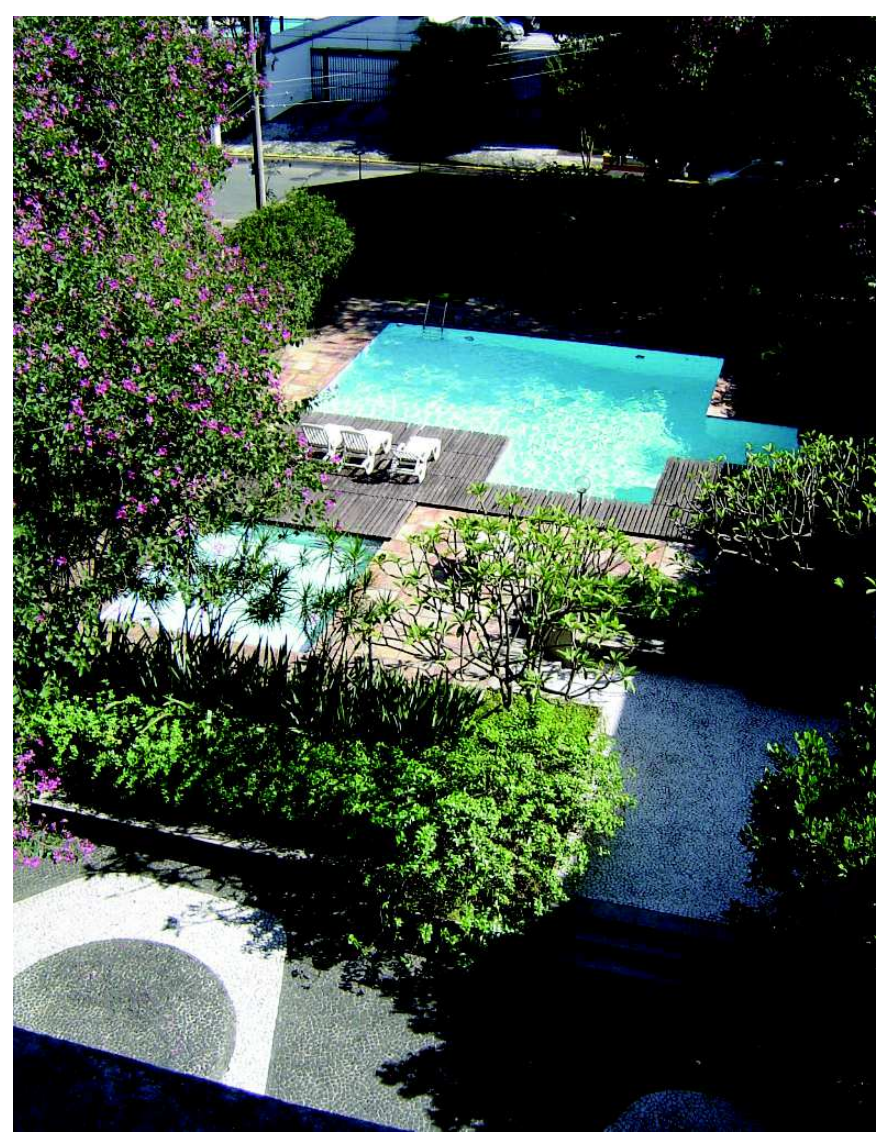

Figura 7 Edifício Macunaíma,

São Paulo, SP, 2005.

Foto: Acervo Quapá. 


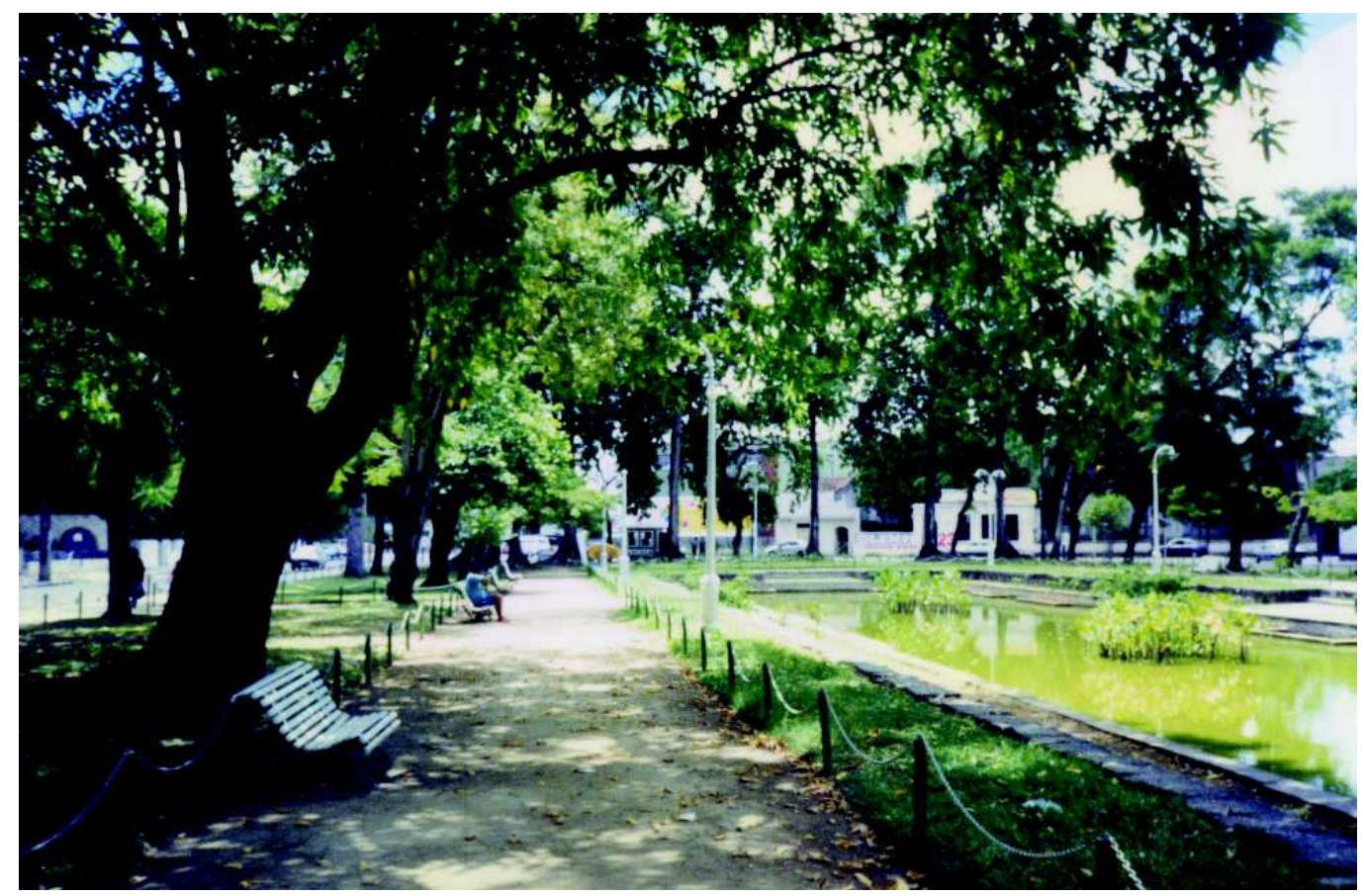

Figura 8 Praça de Casa Forte, Recife, PE.

Foto: Ana Carolina Magalhães, 1996. Acervo Quapá.

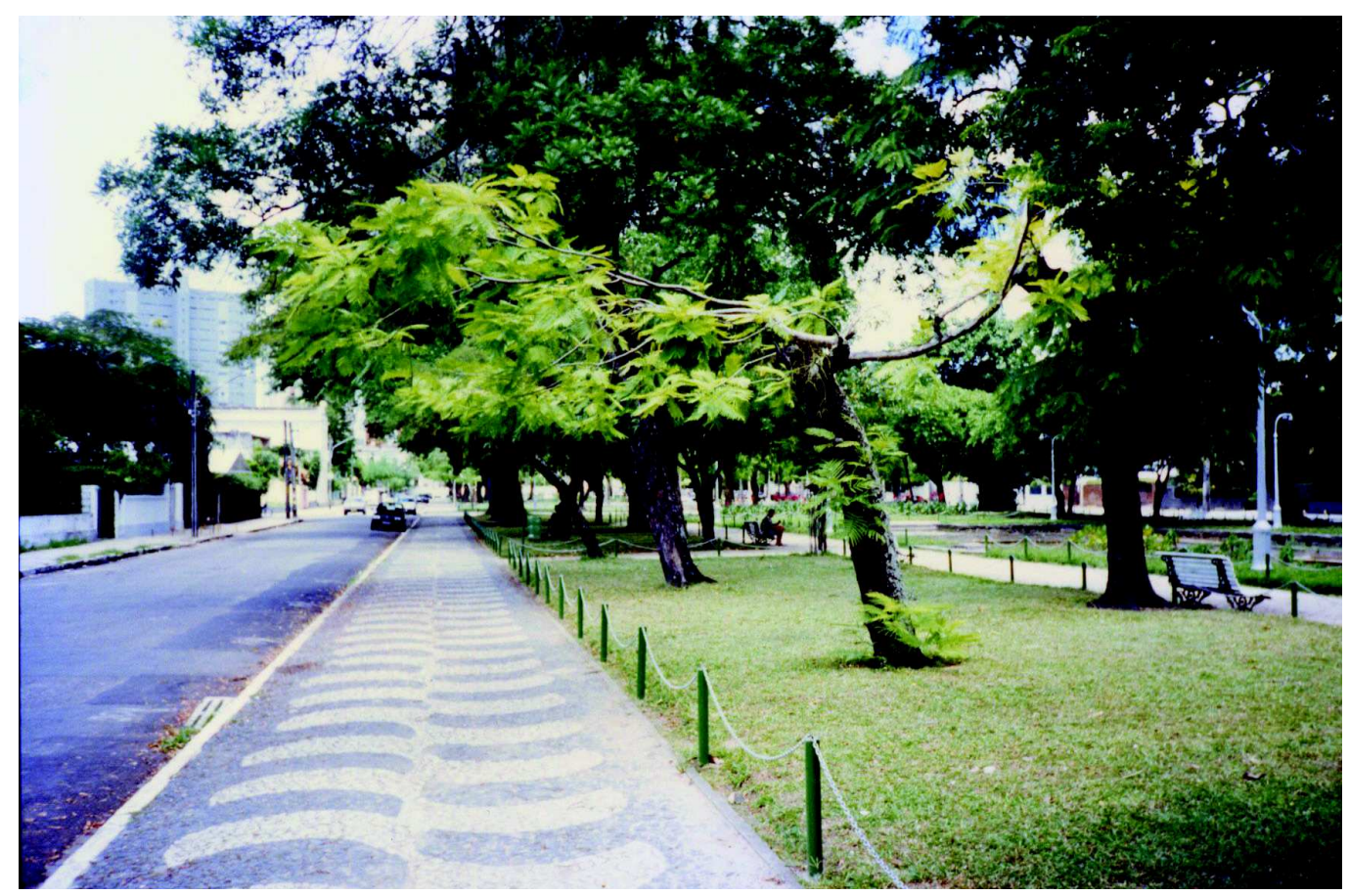

Figura 9 Praça de Casa Forte, Recife, PE.

Foto: Ana Carolina Magalhães, 1996. Acervo Quapá. 


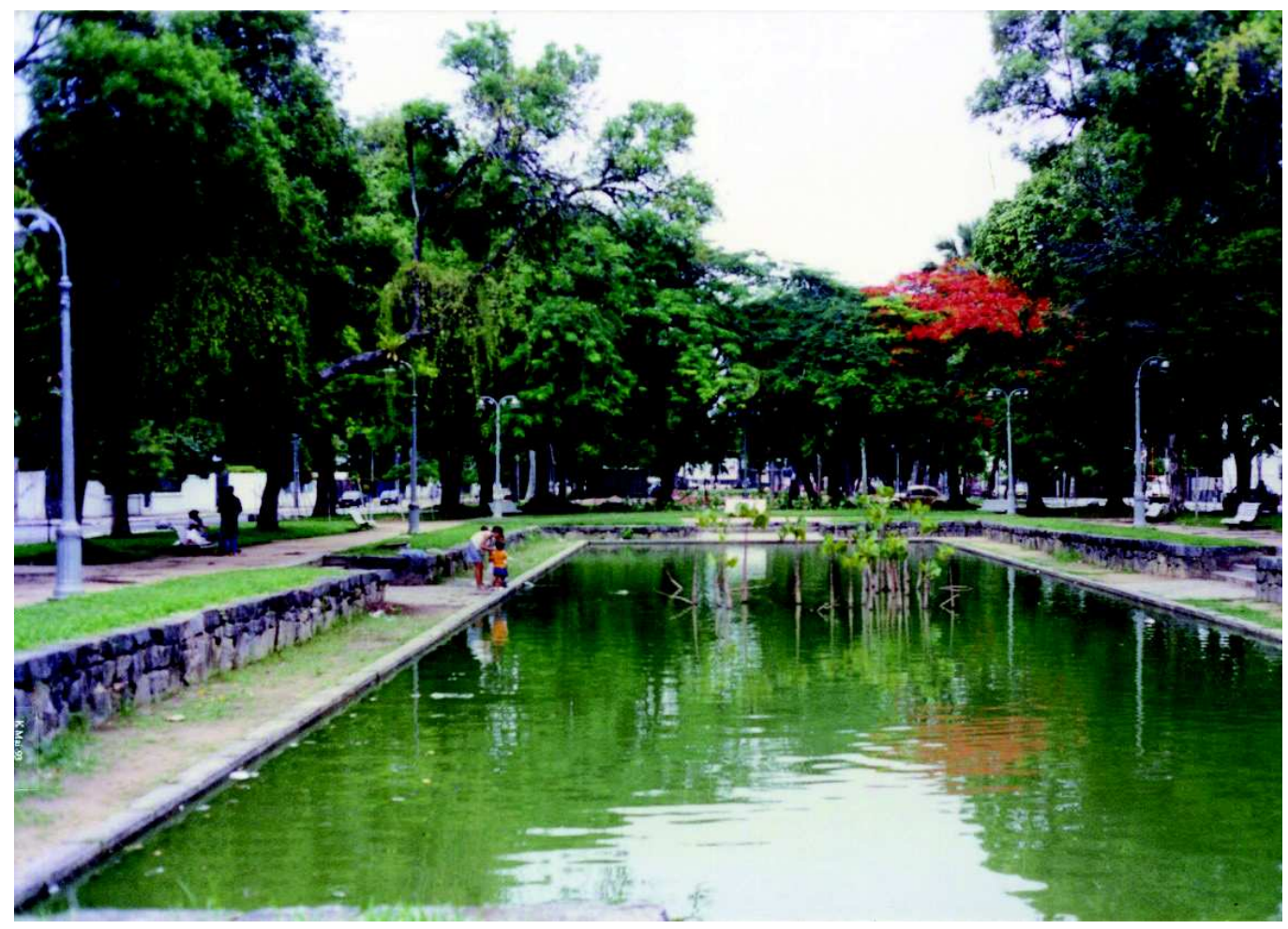

Figura 10 Praça de Casa Forte, Recife, PE.

Foto: Silvio Soares Macedo, 1997. Acervo Quapá.

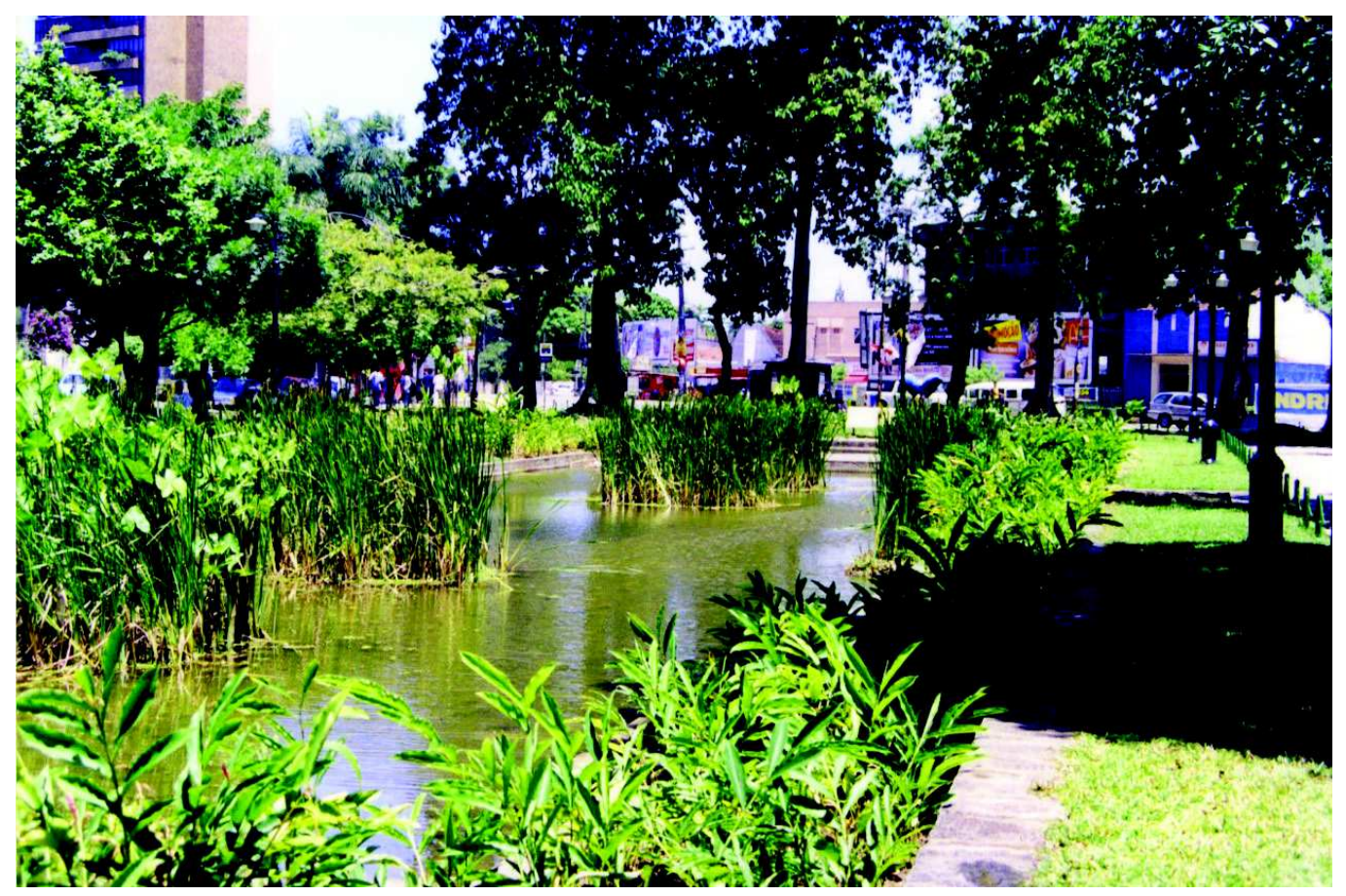

Figura 11 Praça de Casa Forte, Recife, PE,

Foto: Silvio Soares Macedo, 1997. Acervo Quapá 


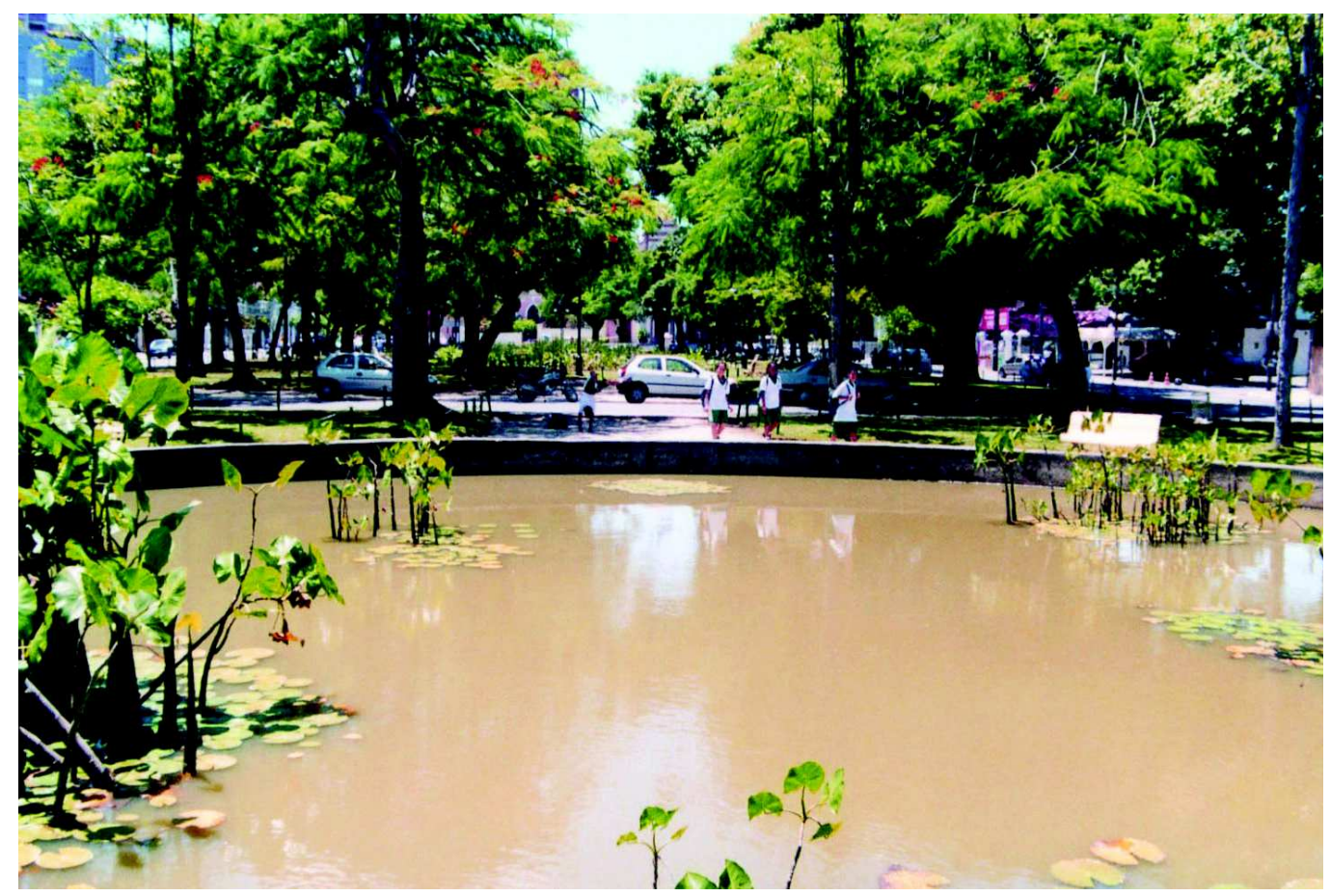

Figura 12 Praça de Casa Forte, Recife, PE.

Foto: Silvio Soares Macedo, 2002. Acervo Quapá.

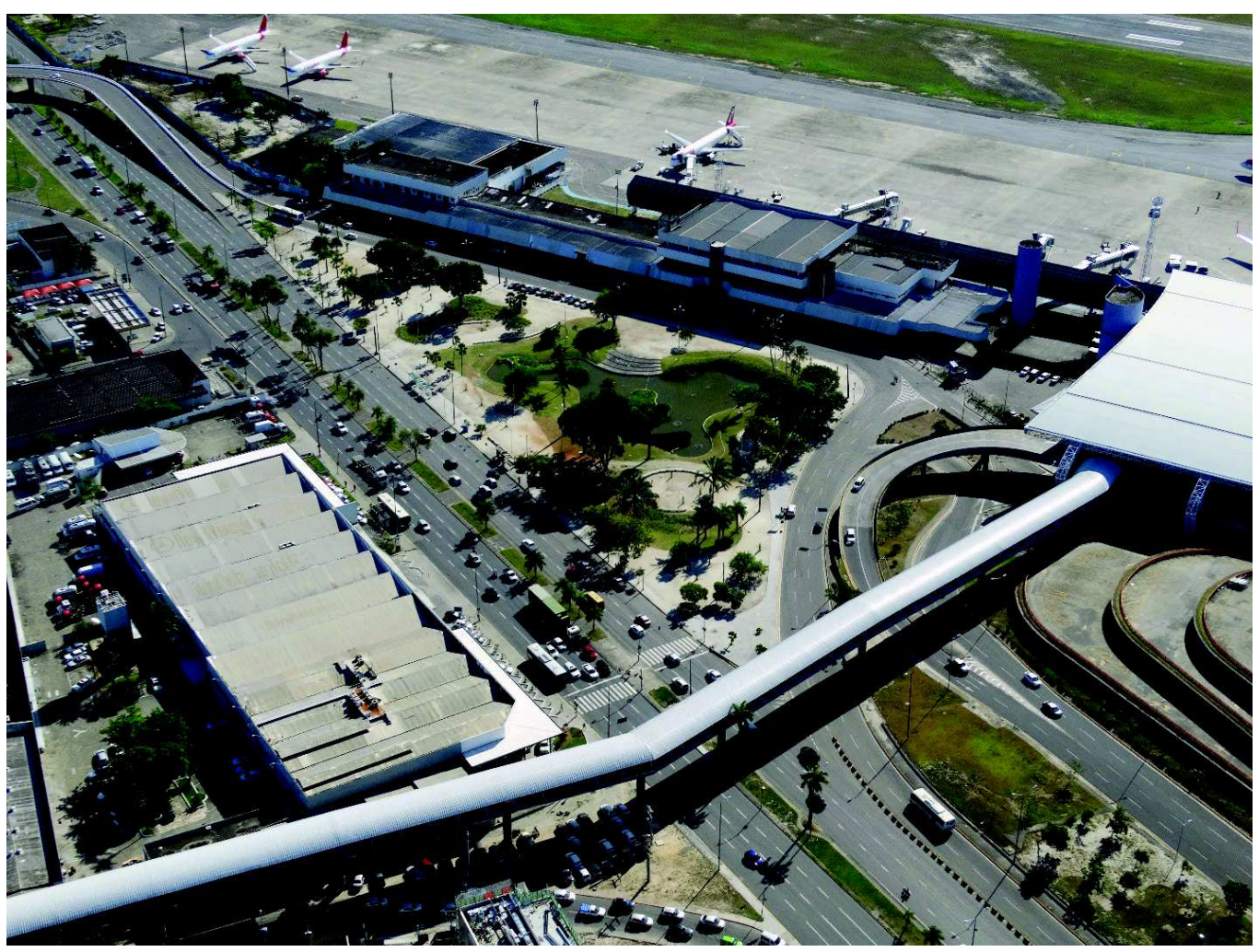

Figura 13 Praça Ministro Salgado Filho, Recife, PE. Foto: Silvio Soares Macedo, 2014. Acervo Quapá. 


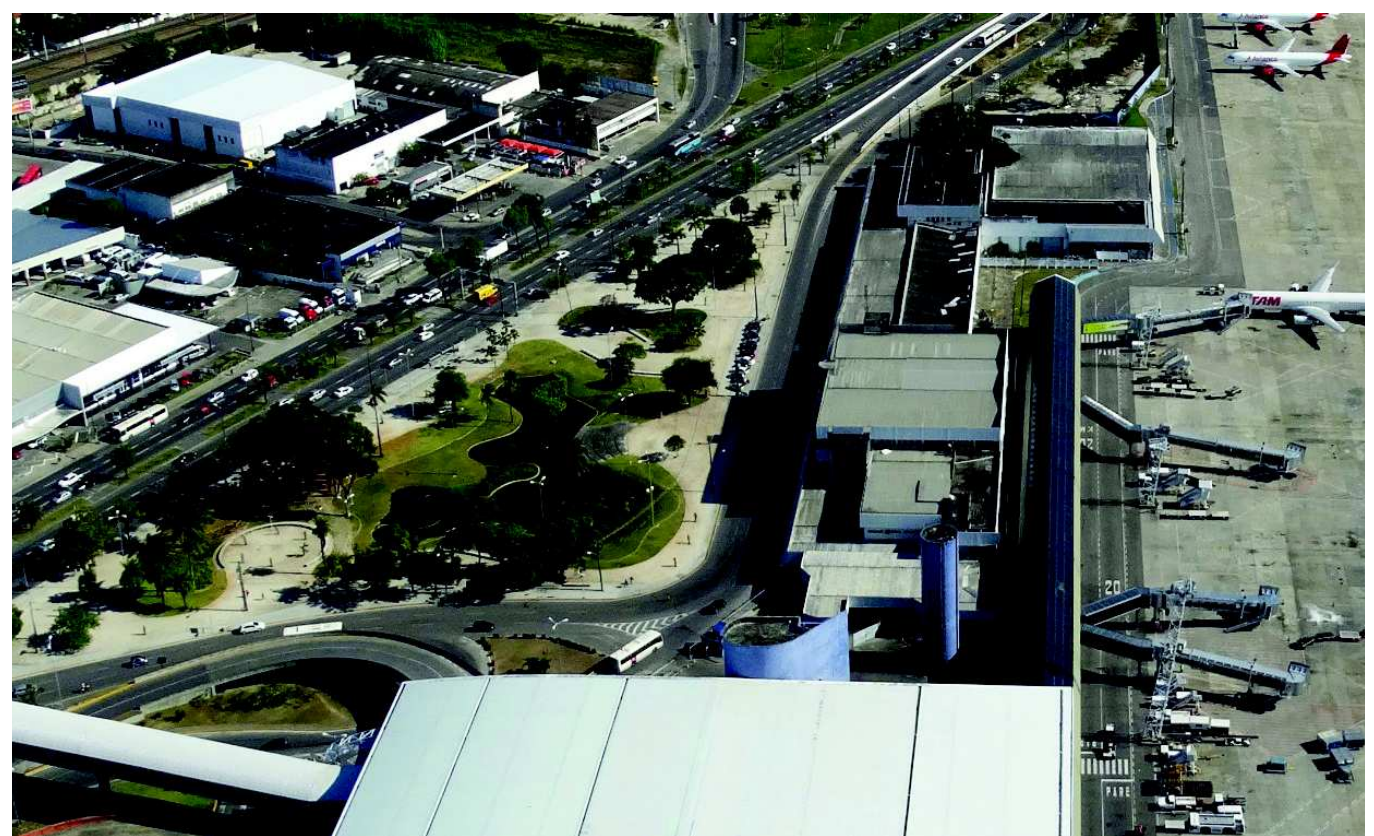

Figura 14 Praça Ministro Salgado Filho, Recife, PE.

Foto: Silvio Soares Macedo, 2014. Acervo Quapá.

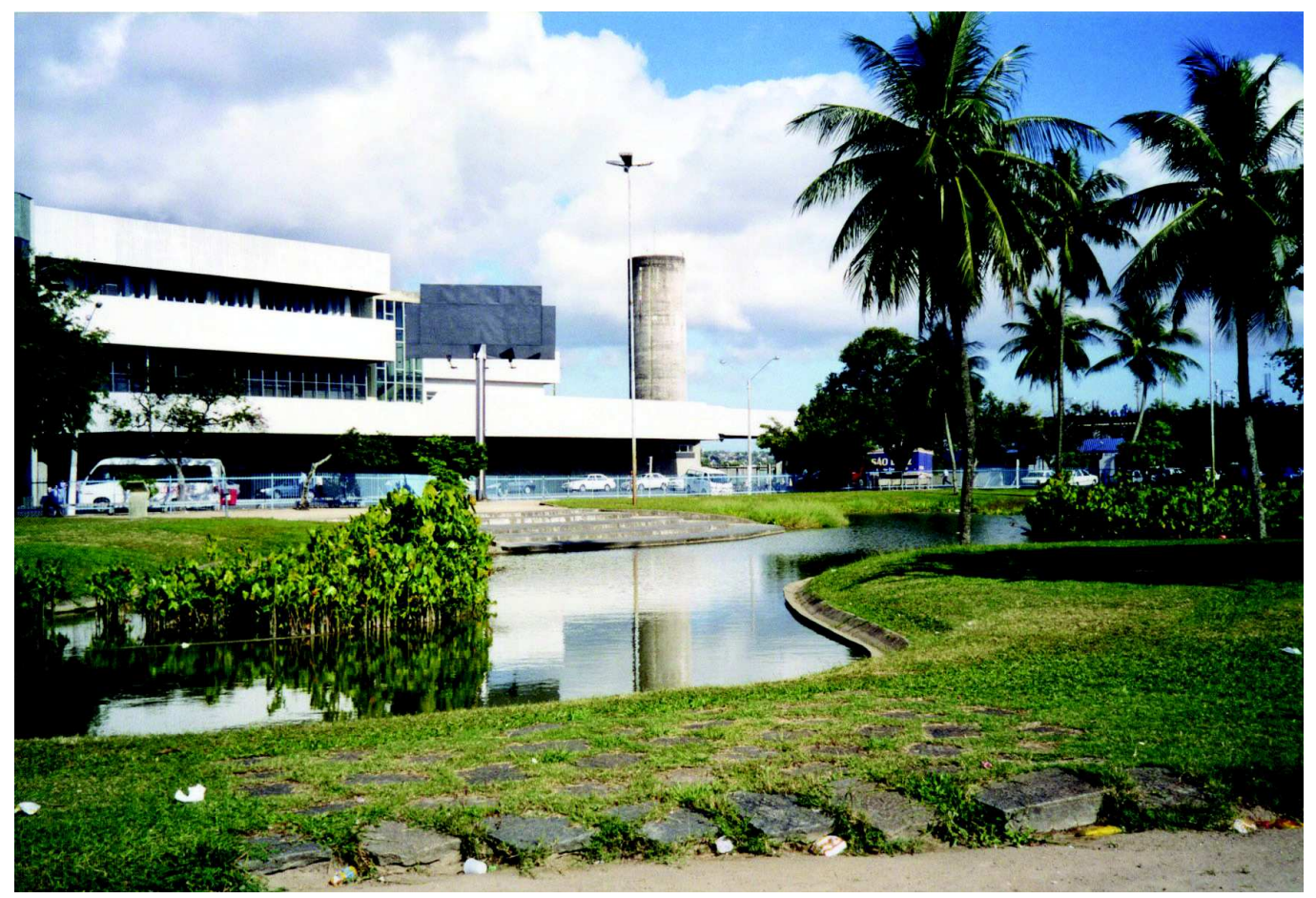

Figura 15 Praça Ministro Salgado Filho, Recife, PE.

Foto: Silvio Soares Macedo, 2014. Acervo Quapá. 


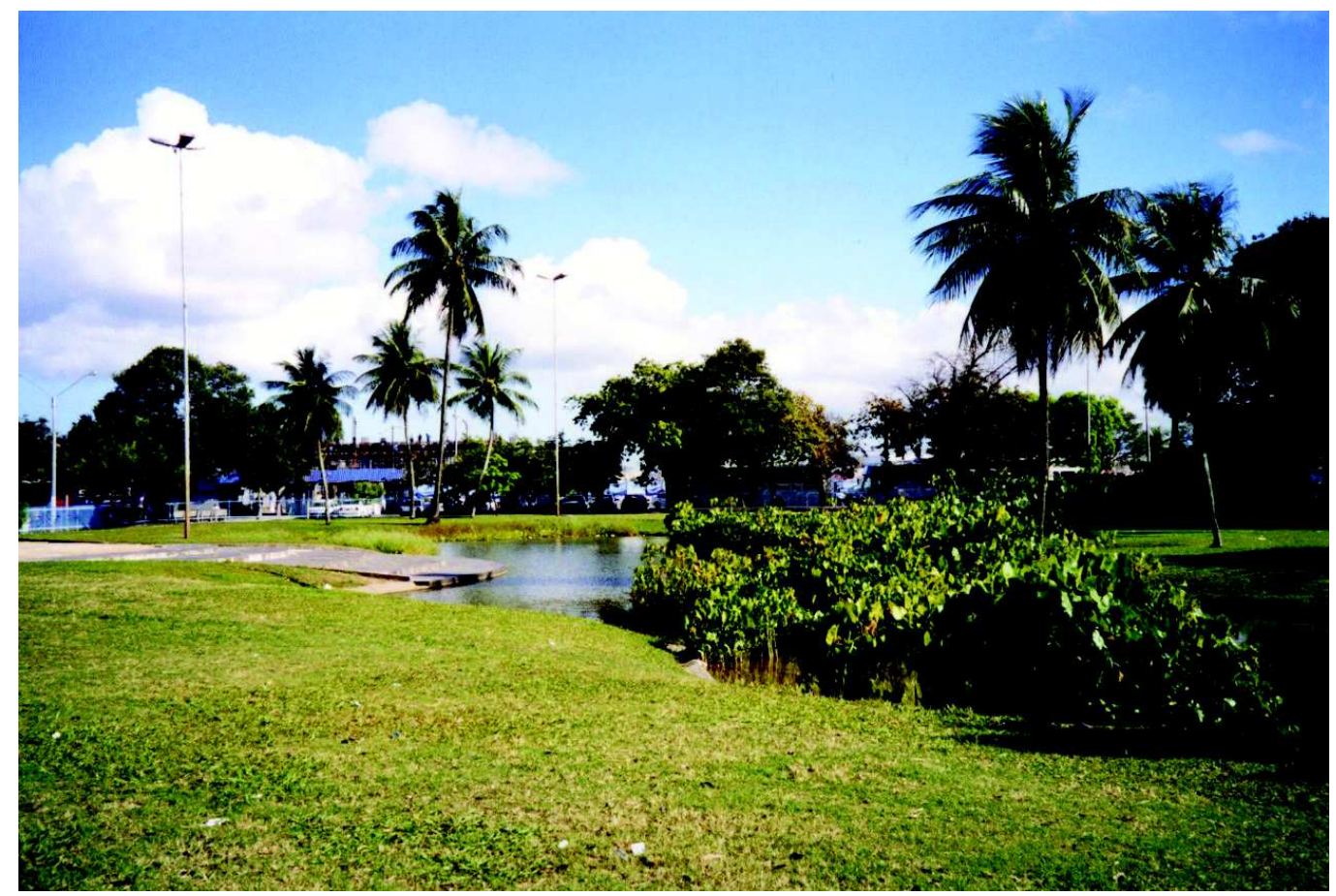

Figura 16 Praça Ministro Salgado Filho, Recife, PE. Foto: Silvio Soares Macedo, 2014. Acervo Quapá.

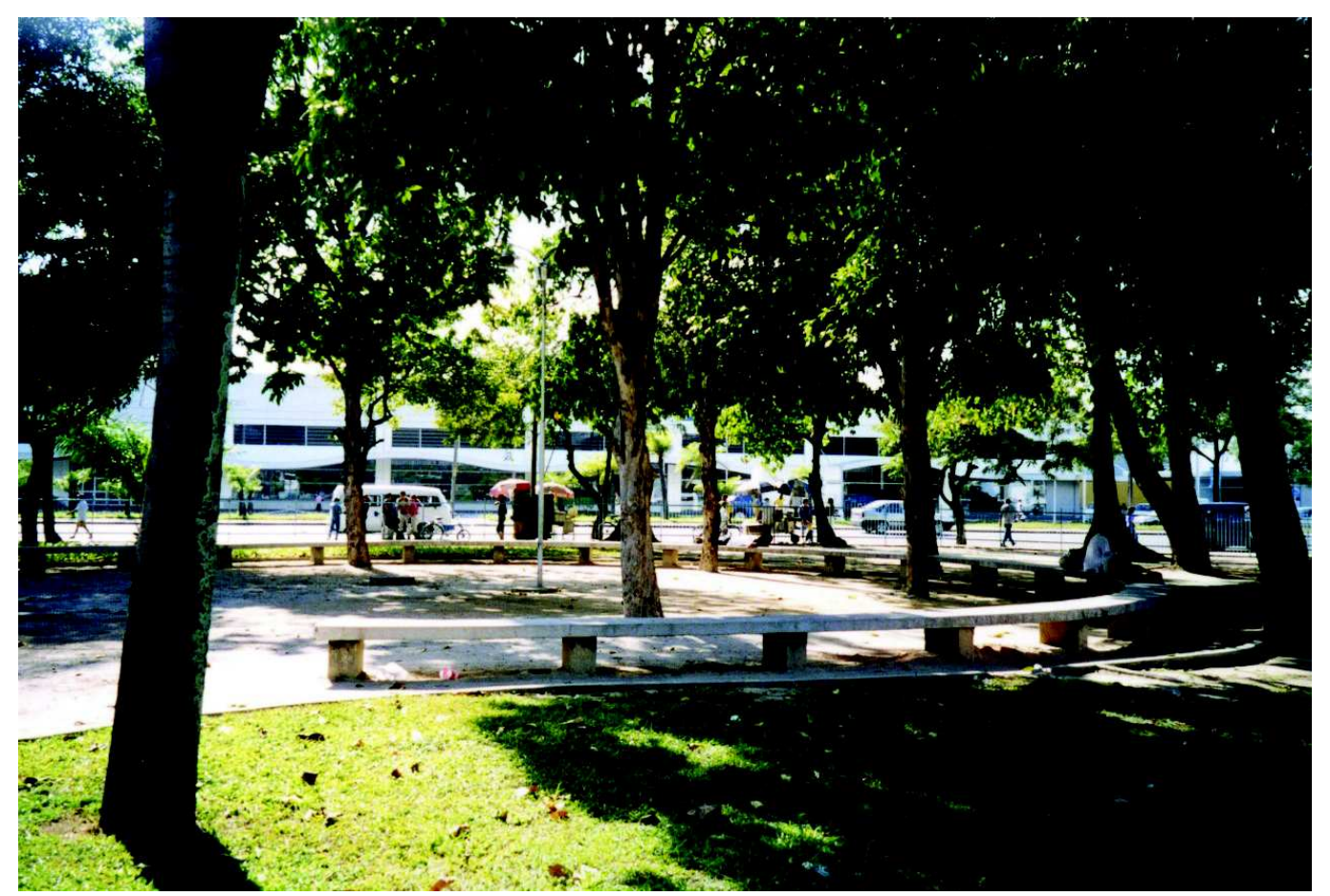

Figura 17 Praça Ministro Salgado Filho, Recife, PE. Foto: Silvio Soares Macedo, 2014. Acervo Quapá. 


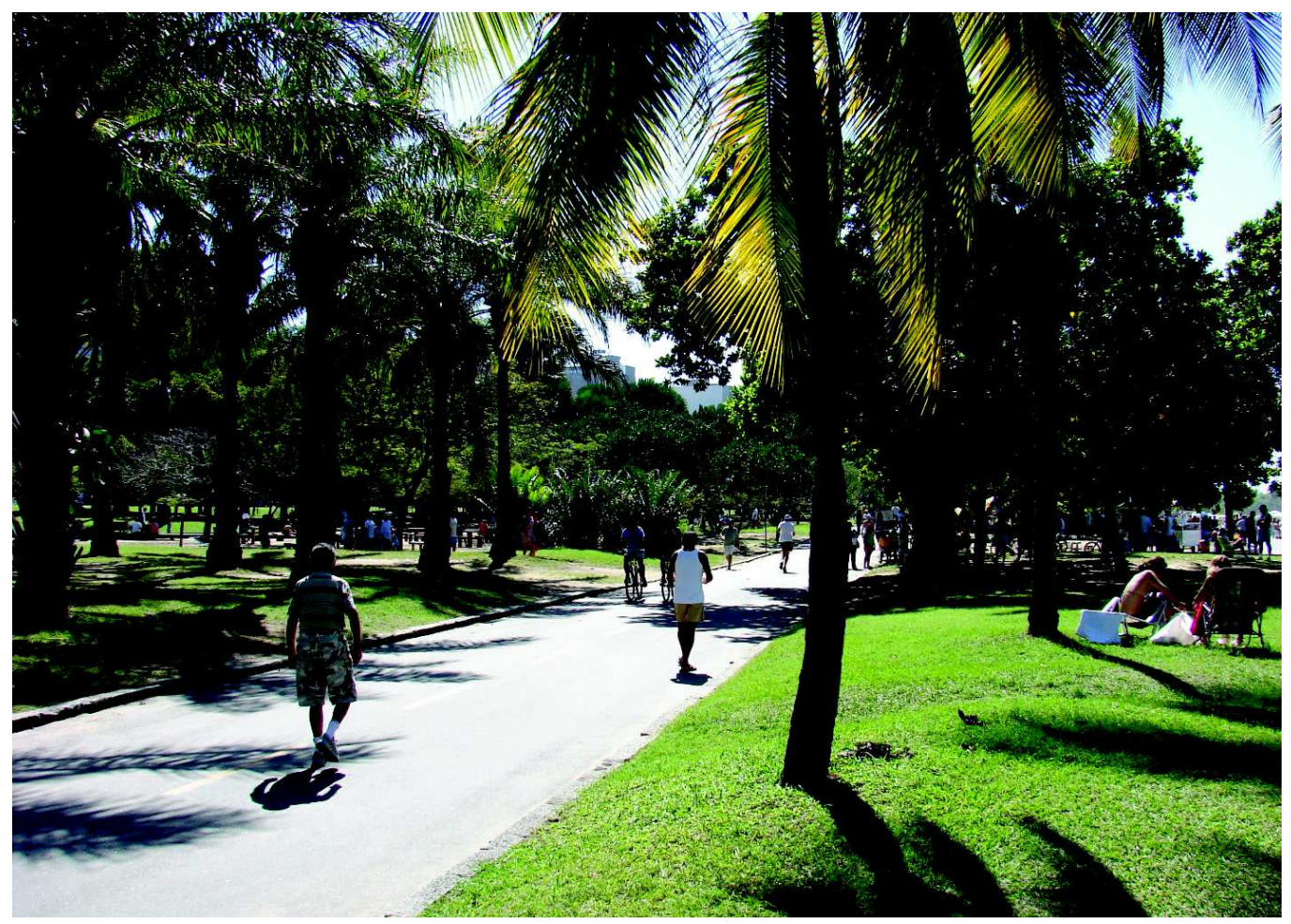

Figura 18 Aterro do Flamengo, Rio de Janeiro, RJ, 2008. Foto: Acervo Quapá.

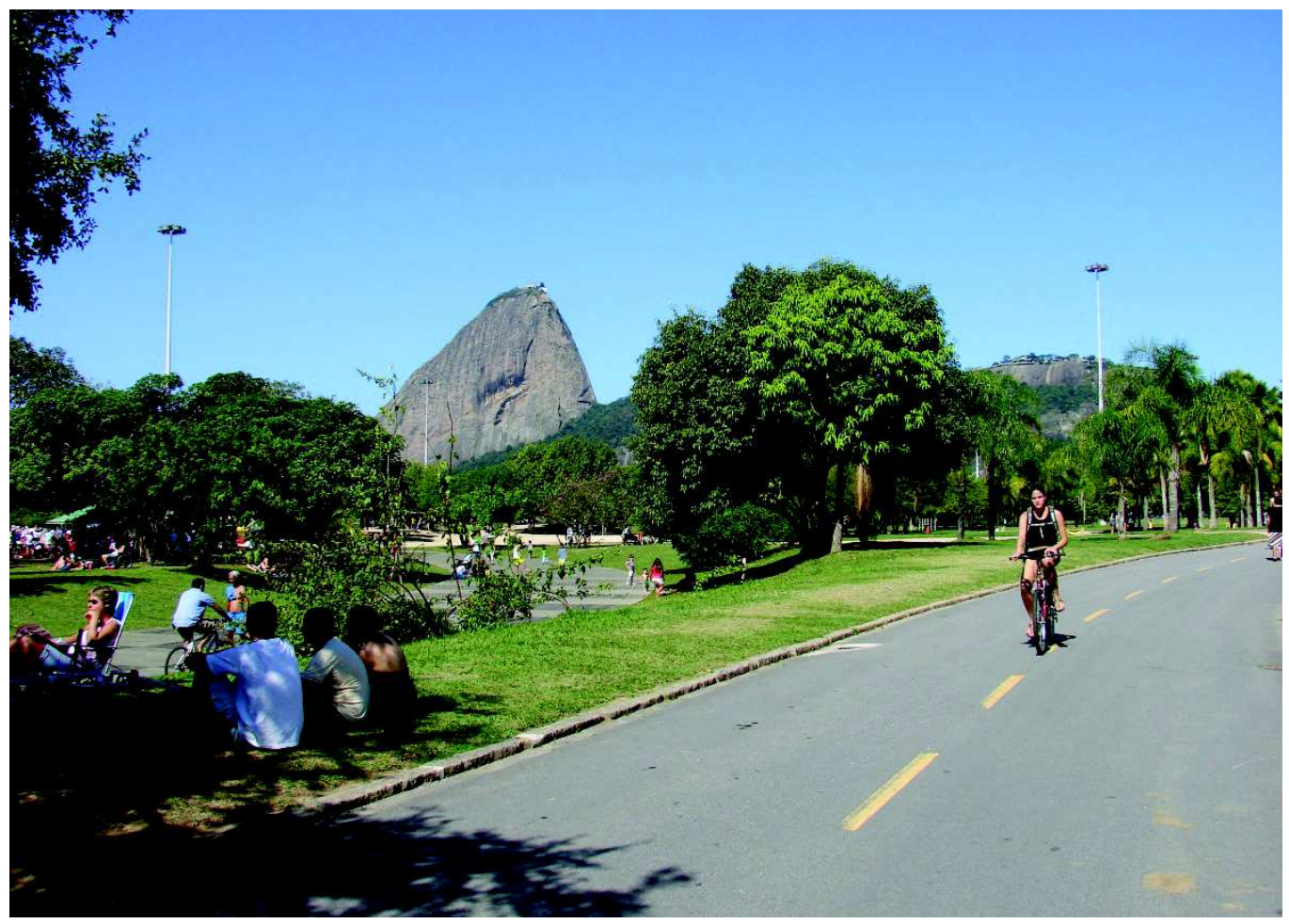

Figura 19 Aterro do Flamengo, Rio de Janeiro, RJ, 2008.

Foto: Acervo Quapá 


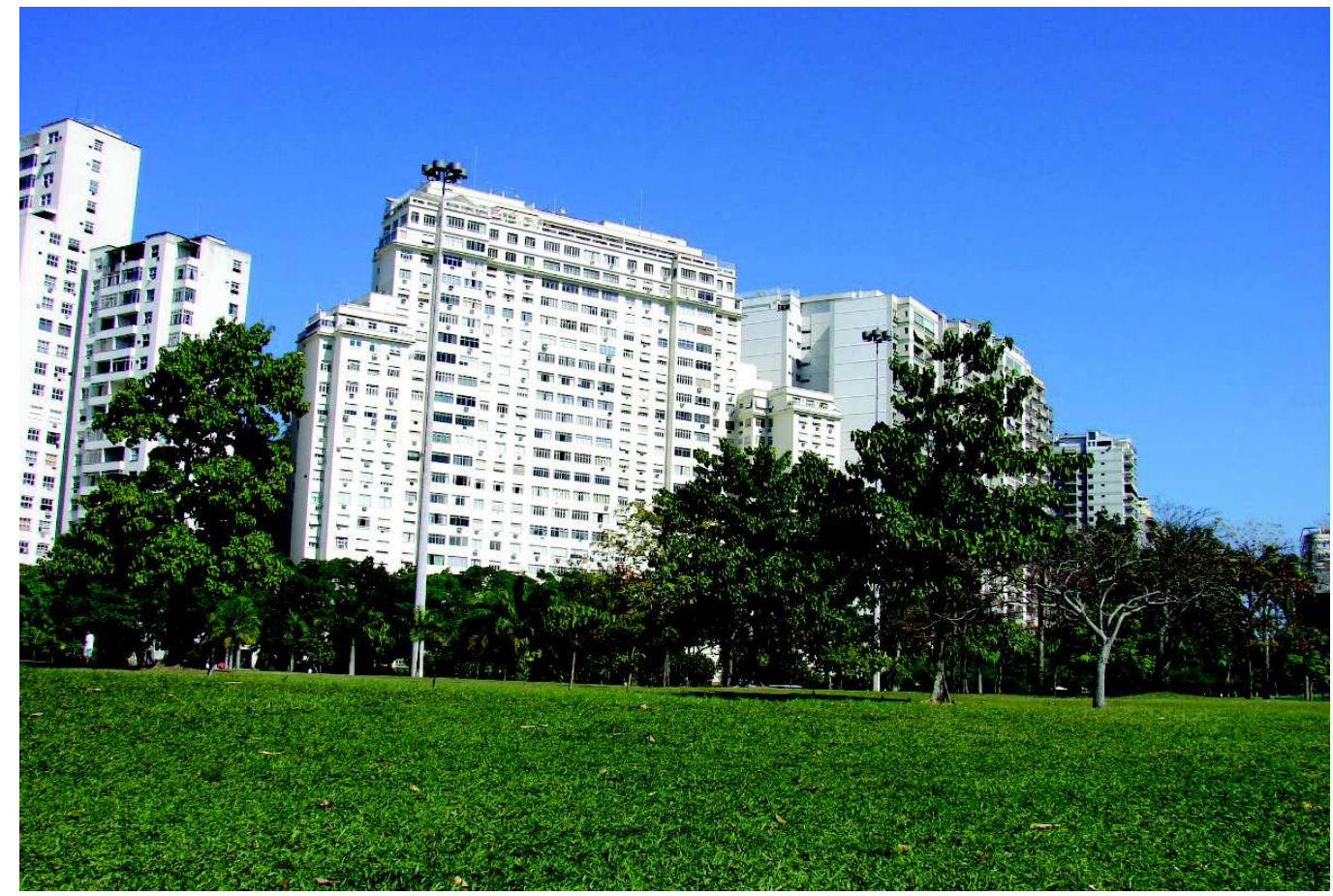

Figura 20 Aterro do Flamengo, Rio de Janeiro, RJ, 2008. Foto: Acervo Quapá.

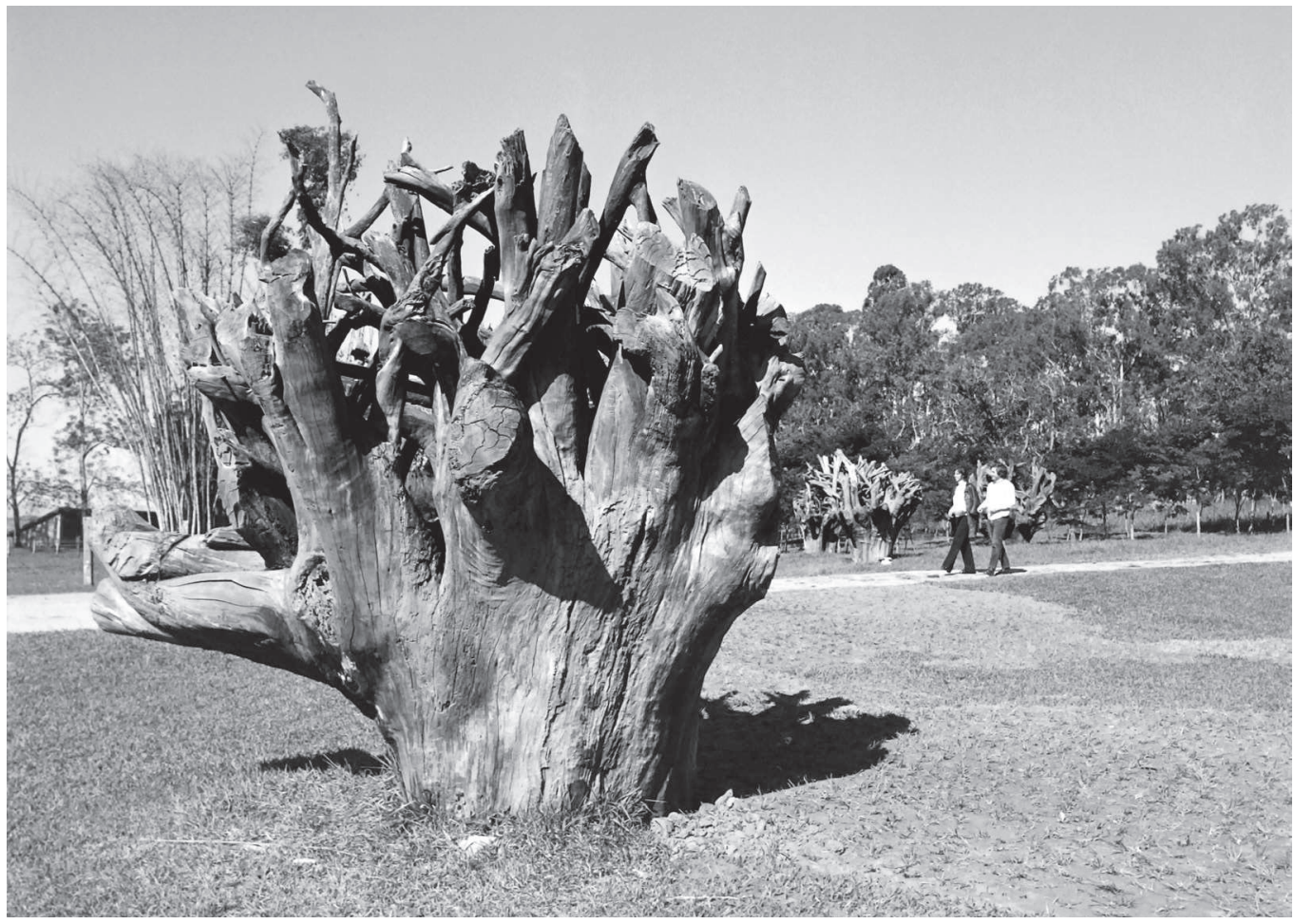

Figura 21 Residência de Olivio Gomes, projeto de Rino Levi, Roberto Cerqueira César e Burle Marx. Vale do Paraíba, São José dos Campos, SP, c. 1970.

Foto: Marcel Gautherot / Acervo Instituto Moreira Salles 


\section{AS PAISAGENS DE BURLE MARX: UM ADÁGIO PARA O FUTURO}

A paisagem nas cidades foi tema contínuo de reflexão na carreira de Burle Marx. A preocupação com os efeitos do vertiginoso crescimento urbano, perturbador do caráter das cidades, deformando a essência da vida, representava para ele um incômodo constante. Em conferência proferida em 1983, Marx retratava agressões crescentes à natureza, que dizimavam a vegetação original devido à especulação mobiliária, invadindo vorazmente seus morros e eliminando suas perspectivas. (MARX, 2004g).

Quando falava sobre as consequências ecológicas da construção sem critérios, por exemplo, a abertura de autoestradas como a Rio-Santos, o paisagista salientava que aquele tipo de intervenção não ocasionava somente a destruição da fauna e da flora, mas a destruição de "[...] uma paisagem de valor cênico incalculável [...]" (MARX, 2004h, p. 149).

Burle Marx atentava para questões relacionadas à urbanização que impactavam em demasia a profissão dos paisagistas. Em sua visão, o aumento agressivo da densidade populacional produzido pela verticalização das cidades impactava a qualidade dos padrões de conforto. Além disso, o sacrifício das áreas verdes por razões imobiliárias sem a compensação necessária transformava as cidades em regiões áridas, com pouca sombra, sem enumerar a aniquilação do patrimônio arquitetônico para ceder espaço às novas construções. "Esquecem-se de que a coexistência dos tempos, cristalizada no trabalho acumulado de muitas gerações, é um dos principais encantos das cidades." (MARX, 2004g, p. 186).

No turbilhão de ações desfavoráveis para a vida nas cidades, Burle Marx destacava a importância dos jardins. Apesar de os parques e praças públicas serem considerados espaços de lazer e de contemplação, ainda não eram projetados com o rigor necessário para atender às necessidades de uma população atormentada pelo caos das cidades. Como ele mesmo colocou, os projetos dos espaços públicos, sejam na cidade ou no interior, "[...] nada acrescentam à nossa formação já tão fraca no que se concerne ao conhecimento da flora autóctone". (MARX, 2004g, p. 186).

Suas inquietações na década de 1980 já refletiam uma preocupação profunda a respeito da sustentabilidade do Brasil. Como Burle Marx reagiria ao ver a situação das nossas grandes cidades e a negligência de tantos atores sociais em relação à natureza nos espaços urbanos hoje? Passaram-se mais de três décadas e continuamos a cobiçar os mínimos espaços restantes na selva de concreto, muitas vezes não refletindo sobre as consequências em nossas vidas.

Acreditando que a natureza presente nos parques, praças, ruas e hortos representava "[...] um patrimônio digno de ser defendido, conservado, divulgado por todos os meios [...]", Marx, em uma conferência proferida em 1966, disse:

[...] o homem da cidade está mais do que espremido e sufocado em sua moradia, onde a ordem é 'mínimo standards', há necessidade de se criar grandes espaços livres, onde se possa respirar, entrar em contato com a natureza, ter a oportunidade 
de poder meditar, contemplar uma flor ou uma forma vegetal num lugar sossegado [...] (MARX, 2004b, p. 74).

Para ele, o contato do homem com a natureza e, particularmente, a educação dos jovens para os processos naturais, oferecia uma solução para a preservação do meio ambiente nas cidades brasileiras, sendo a única medida viável para salvar o país da desertificação total, assegurando como herança das futuras gerações uma vida mais equilibrada:

Devemos fazer nossos filhos entrar em contato com a natureza, compreender o patrimônio que possuem. Fazê-los plantar, compreender a importância das árvores, ensinar-lhes a não mutilá-las. Mostrar-Ihes a importância da associação de plantas da ecologia. Ensinar-lhes a coletar sementes, semear, plantar as pequenas mudas, ter amor por elas, para que possam medrar. Que passem a ver as plantas como seres vivos, que têm o direito de crescer, florindo, frutificando, incutindo neles a importância da perpetuação, a maravilha da expectativa de uma formação de botões, desabrochando em floração. Ensinar-lhes a observar a riqueza do fenômeno da fecundação - às vezes feita por abelhas, outras por pássaros, pelo vento ou pela água. Passar a ver esse complexo que é a natureza, onde as associações mais assombrosas despertam emoções estéticas, provocadas pela forma, pelos ritmos, pela exuberância das cores. (MARX, 2004g, p. 186-188).

Como defendido por Burle Marx anos atrás, e evidenciado hoje por extensas pesquisas em diversas áreas, a criança é peça fundamental no processo de proteção, divulgação e conservação da natureza, além de ser abundantemente beneficiada pelo contato direto com o mundo natural. Um exemplo desse vínculo foi descrito pelo arquiteto e urbanista americano Robin Moore, através de uma pesquisa com bebês em que descreveu o fascinante aprendizado por meio de experiências na natureza de um menino de dez meses de vida que, vestindo apenas fraldas, nota um grilo em uma pedra no jardim - uma experiência direta que exemplifica o poder e a simplicidade de como a natureza ensina. $O$ menino vai até o grilo e pausa por alguns minutos, apenas observando o inseto, e tenta pegá-lo. O grilo pula e aterrissa em um tronco de árvore. O pequenino segue até ele novamente e, observando-o curiosamente, chega muito perto do animal, e o grilo pula novamente, escondendo-se. (MOORE; COSCO, 2000). Os autores explicam que após o contato com essa nova criatura, a visão do mundo da criança ganha mais uma dimensão. Na próxima vez em que se deparar com um fenômeno similar, seja no contato com um besouro ou uma borboleta, seu primeiro passo será reativado pela experiência anterior. Assim, vai construindo um entendimento dos seus arredores e de como a natureza opera. Um adulto pode complementar essas experiências através da leitura de livros com fotos desses animais e explicando quantidades, cores e sons. (MOORE; COSCO, 2000).

Muitas crianças, atualmente, contemplam a natureza através da tecnologia, e não de experiências diretamente vividas. Como, então, sensibilizar esses futuros cida- 
dãos para o meio ambiente? Os jardins de Burle Marx despontam como poderosas ferramentas de estimulação dos sentidos, tão necessárias a crianças e adultos. Há séculos a natureza vem sendo defendida, por exemplo, como um "[...] tônico calmante e intensificador da criatividade [...]" e um lugar onde, como explicou Thoreau, "[...] meus nervos são estabilizados, meus sentidos e minha mente fazem seu trabalho"14. (CRAMER, 2007, p. 302).

Burle Marx (2004) defendia a presença de natureza nos espaços públicos e, consequentemente, deixou importantes ensinamentos sobre estruturas urbanas, como os parques - que, como ele mesmo dizia, "[...] são essenciais na vida urbana". São locais de disseminação da riqueza da natureza, da criação de paisagens que toquem e sejam percebidas pela população. Um parque, como descrito pelo paisagista - com dimensões apropriadas para cada cidade, com um horto, plantação intensiva e diversidade de espécies para enriquecer jardins, ruas, praças, e capaz de fornecer experiências no campo da botânica - tem dimensões muito mais significativas para a população do que podemos pressupor.

Explorar e afiliar-se com a vida são processos complicados no desenvolvimento mental humano. Muitas teorias a respeito do relacionamento do homem com a natureza tentam explicar tendências, atitudes e percepções. Mesmo a corrente biofílica, cunhada por Edward O. Wilson ${ }^{15}$ (1984), que discorre sobre a tendência inata do homem de afiliar-se à natureza e seus processos, seria insuficiente para explicar o que cada um vivencia quando está em um espaço criado por Burle Marx. Suas paisagens tropicais eclodem sentimentos ímpares, que são constantemente transformados de acordo com o momento em que elas são percebidas.

Os espaços deixados pelo mestre das paisagens brasileiras despertam, ainda hoje, emoções variadas. O olhar sensível em suas obras, fruto da contemplação da natureza harmoniosa e cautelosamente manipulada, é despertado através do uso de cores, texturas, linhas orgânicas e uma geometria que não agride, mas controla delicadamente a natureza e a conecta com o entorno, criando lugares únicos que provocam seus vivenciadores. Seus projetos despertam a conexão do homem com o lugar e com a natureza. $\bigcirc$ artista se foi, suas paisagens ficaram; cabe ao homem preservá-las para que continuem sensibilizando gerações futuras.

14 "[...] My nerves are stabilized, my senses and my mind do their work [...]". O texto em português é uma tradução livre feita pela pesquisadora.

15 Edward O. Wilson, biólogo americano e ganhador do prêmio Pulitzer usou o termo biofilia para descrever a tendência de focar na vida e nos processos naturais. Temos uma "[...] tendência congênita de nos afiliarmos com outras formas de vida e isso se reflete no nosso cotidiano". (WILSON, 1984, p. 1). A biofilia é uma proposta que tem sido estudada para entender a relação do homem com a natureza em seus conceitos mais básicos. Wilson explica que a tendência biofílica, apesar de não ser objeto de estudo científico que comprove sua veracidade, "[...] é claramente evidente na vida cotidiana". (WILSON, 1984, p. 85); ela se desdobra em fantasias e respostas de indivíduos desde a infância. 


\section{CONSIDERAÇÕES FINAIS}

Burle Marx demonstrou, através do paisagismo e da arte, como o respeito pela natureza pode ser transformado em paisagens dignas de despertarem o olhar sensível humano. Seus conceitos sobre natureza, paisagem e arte tocaram aqueles que alguma vez já presenciaram qualquer de suas obras. Seu legado projetual, verdadeira manifestação artística, representa a forte dimensão teórica que norteou suas transformações da natureza para criar paisagens; um dos únicos brasileiros, até hoje, a aventurar-se por essas veredas com tanto triunfo.

Foi exposto neste texto como o campo do paisagismo pode contribuir para o enriquecimento da questão da paisagem através do legado deixado por Roberto Burle Marx. Suas obras, monumentos dedicados à flora brasileira, agregam o processo de criação da paisagem, através da sensibilidade do paisagista, à luta pela conservação ambiental e a um amor infindável pela natureza. Sua experiência profissional e pessoal deixa a missão de educar a juventude para que suas paisagens sejam protegidas. Que a definição de paisagem seja polissêmica não há dúvidas, e as paisagens de Burle Marx indicam que o paisagismo brasileiro pode contribuir significativamente para $\bigcirc$ aprofundamento desses significados. A incerteza que impera é: como preservar suas paisagens para que continuem contribuindo no despertar de emoções e sentimentos aquietando nossas almas? Em uma de suas últimas conferências, proferida em 1991, sobre arte, ciência e paisagismo, e que não merece ser parafraseada, Marx disse:

A vida é função de um grande mistério que nos envolve cada vez mais. [...] Deus é o criador supremo, o Onisciente e, assim sendo, incapaz de dúvida ou curiosidade. Logo, quanto mais d'Ele nos aproximarmos, imitando-o na sua qualidade criativa, menos sentiremos o acicate da curiosidade (dentre outros desconfortos é claro). Assim, considerando, a arte funciona como uma espécie de mágica, da mesma forma que, quando nas cavernas pré-históricas, o caçador pintava os animais para ganhar o poder de caçá-los. Assim, considerando, a mesma coisa que moveu nossos ancestrais artistas trogloditas continua movendo cada ato de arte atual num esforço de compreensão e para melhor podermos nos situar no universo. (MARX, 2004, p. 219).

\section{REFERÊNCIAS BIBLIOGRÁFICAS}

ASSUNTO, Rosario. Il paesaggio e I'estetica (1971). Palermo, Edizioni Noveccnto, 1994, p. 497.

A paisagem e a estética. In: SERRÃO, Adriana Veríssimo. Filosofia da paisagem: uma antologia. Lisboa: Centro de Filosofia da Universidade de Lisboa, 2013, p. 341-375.

BERQUE, Augustin. (1994). Cinq propositions pour une théorie du paysage. In: BARTALINI, Vladimir. Paisagem, meio, história. Tradução de Vladimir Bartalini para uso exclusivo da disciplina AUP 5810, Paisagismo. São Paulo: FAUUSP, $1^{\circ}$ sem, 2012, p. 26-41.

CRAMER, Jeffrey (Ed.). I to myself: an annotated selection from the Journal of Henry D. Thoreau. Yale University Press, 2007. p. 302.

DOURADO, Guilherme Mazza. Modernidade verde: jardins de Burle Marx. São Paulo: SENAC, 2009. 
FERRIOLO, M. V. (1997). Joachim Riter e a teoria do cosmos como "fundamento da paisagem". In: BARTALINI, Vladimir. Paisagem textos. Tradução de Vladimir Bartalini com a finalidade exclusiva de subsidiar as disciplinas AUP 5834, A paisagem no desenho do cotidiano urbano, e AUP 5882, Paisagem e arte - intervenções contemporâneas. São Paulo: FAUUSP, $2^{\circ}$ sem. 2013.

MARX, Burle. Arte, ciência e paisagismo. In: TABACOW, José. Roberto Burle Marx: arte e paisagem. São Paulo: Studio Nobel, 2004, p. 215-219.

Conceitos de composição em paisagismo. In: TABACOW, José. Roberto Burle Marx: arte e paisagem. São Paulo: Studio Nobel, 2004a, p. 23-24.

Considerações sobre arte brasileira. In: TABACOW, José. Roberto Burle Marx: arte e paisagem. São Paulo: Studio Nobel, 2004b, p. 69-75. $\overline{85-95 .}$

Jardim e ecologia. In: TABACOW, José. Burle Marx: arte e paisagem. São Paulo: Studio Nobel, 2004 c, p.

Recursos paisagísticos do Brasil. In: TABACOW, José. Burle Marx: arte e paisagem. São Paulo: Studio Nobel, 2004d, p. 127-137.

. $O$ jardim como forma de arte. In: TABACOW, José. Burle Marx: arte e paisagem. São Paulo: Studio Nobel, 2004e, p. 51-68.

Paisagismo e ecologia. In: TABACOW, José. Roberto Burle Marx: arte e paisagem. São Paulo: Studio Nobel, 2004f, p. 159-170.

O paisagismo na estrutura urbana. In: TABACOW, José. Roberto Burle Marx: arte e paisagem. São Paulo: Studio Nobel, 2004g, p. $181-190$

Problemas de conservação da natureza. In: TABACOW, José. Roberto Burle Marx: arte e paisagem. São Paulo: Studio Nobel, 2004h, p. 147-158.

McHARG, lan L. A quest for life: an autobioghraphy. New York: Wiley \& Sons, Inc., 1996.

MOORE, R. C.; COSCO, N. G. Developing an earth-bound culture through design of childhood habitats. International conference on Faculty of Social Sciences. People, land and sustainability, 2000, p. 13-16.

NYS, Philippe. (1997). Paisagem. Função da estética na sociedade moderna. In: BARTALINI, Vladimir. Paisagens textos. Tradução de Vladimir Bartalini com a finalidade exclusiva de subsidiar as disciplinas AUP 5834, A paisagem no desenho do cotidiano urbano, e AUP 5882, Paisagem e arte - intervenções contemporâneas. São Paulo: FAUUSP, $2^{\circ}$ sem. 2013 , p. 30-38.

PETRARCA, Francesco. (1336). A subida ao Monte Ventoux. In: BARTALINI, Vladimir. Paisagens textos. Tradução de Vladimir Bartalini, com a finalidade exclusiva de subsidiar as disciplinas AUP 5834, A paisagem no desenho do cotidiano urbano, e AUP 5882, Paisagem e arte - intervenções contemporâneas. São Paulo: FAUUSP, $2^{\circ}$ sem. 2013, p. 68-72.

QUEIROGA, Eugenio Fernandes. Razão pública e paisagem: reflexões e subsídios teórico-conceituais para o entendimento e para a qualificação da urbanização contemporânea. ENCONTRO NACIONAL DE ENSINO DE PAISAGISMO EM ESCOLAS DE ARQUITETURA E URBANISMO NO BRASIL (ENEPEA), 11, Campo Grande, 2012. Disponível em: <http://www.revistas.usp.br/paam/article/view/971 14>. Acesso em: 8 jul. 2016.

RITTER, J. (1978). Paisagem: função da estética na sociedade moderna. In: BARTALINI Vladimir. Paisagem textos. Tradução de Vladimir Bartalini, com a finalidade exclusiva de subscidiar as disciplinas AUP 5834, A paisagem no desenho do cotidiano urbano, e AUP 5882, Paisagem e arte - intervenções contemporâneas. São Paulo: FAUUSP, $2^{\circ}$ sem. 2013, p. 48-66.

ROGER, Alain. O nascimento da paisagem no Ocidente. In: BARTALINI, Vladimir. COLÓQUIO INTERNACIONAL DE HISTÓRIA DA ARTE, 10, São Paulo, 1999. Tradução de Vladimir Bartalini, com a finalidade exclusiva de subscidiar as disciplinas AUP 5834, A paisagem no desenho do cotidiano urbano, e AUP 5882, Paisagem e arte - intervenções contemporâneas. São Paulo: FAUUSP, $2^{\circ}$ sem. 2013.

SELHUB, Eva M.; LOGAN, Alan C. Your brain on nature: the science of nature's influence on your health, happiness, and vitality. Ontário: John Wiley \& Sons, 2012.

SERRÃO, Adriana Conceição Guimarães Veríssimo. Filosofia e paisagem: aproximações a uma categoria estética. Philosophica, 23, 2004, 78-102.

Filosofia da paisagem: uma antologia. Lisboa: Centro de Filosofia da Universidade de Lisboa, 2014, p.

Paisagem, a unidade de natureza e cultura: origem, essência e cultura de uma ideia. São Paulo: LABBARC. FAUUSP, 2014. 
SIMMEL, Georg. (1913). La tragédie de la culture: et autres essais. In: BARTALINI, Vladimir. Paisagem textos. Tradução de Vladimir Bartalini, com a finalidade exclusiva de subsidiar as disciplinas AUP 5834, A paisagem no desenho do cotidiano urbano, e AUP 5882, Paisagem e arte - intervenções contemporâneas. São Paulo: FAUUSP, $2^{\circ}$ sem. 2013

TABACOW, José. Roberto Burle Marx: arte e paisagem. São Paulo: Studio Nobel, 2004.

TATE LAND ART. (nov. 2015). Disponível em: <http://www.tate.org.uk/learn/online-resources/glossary/l/land-art> . Acesso em: 26 ago. 2016.

WILSON, Edward O. Biophilia. Cambridge: Harvard University Press, 1984.

\section{Nota do editor}

Submetido em: 30 abr. 2015

Aprovado em: 30 nov. 2015 